\title{
Morphologic Studies of
}

Fusulinids From the

Lower Permian of

West Pakistan

GEOLOGICAL SURVEY PROFESIONAL PAPER 643-G

Prepared in cooperation with the Geological

Survey of Pakistan and the Agency for

International Development,

U.S. Department of State

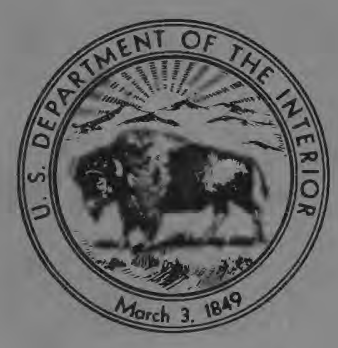


Morphologic Studies of

Fusulinids From the

Lower Permian of

\section{West Pakistan}

By RAYMOND C. DOUGLASS

C O N T R I B U T I O N S T O PAL E O N T O L G Y

GEOLOGICAL SURVEY PROFESIONAL PAPER 643-G

Prepared in cooperation with the Geological

Survey of Pakistan and the Agency for

International Development,

U.S. Department of State

Evidence that comparisons made at equal radii

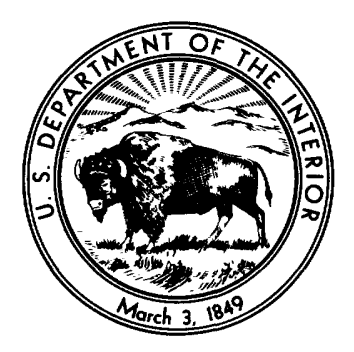

reveal similarities in forms that otherwise

look distinct

UNITED STATES GOVERNMENT PRINTING OFFICE, WASHINGTON : 1970 
UNITED STATES DEPARTMENT OF THE INTERIOR

WALTER J. HICKEL, Secretary

GEOLOGICAL SURVEY

William T. Pecora, Director

For sale by the Superintendent of Documents, U.S. Government Printing Office

Washington, D.C. 20402 - Price 55 cents (paper cover) 


\section{CONTENTS}

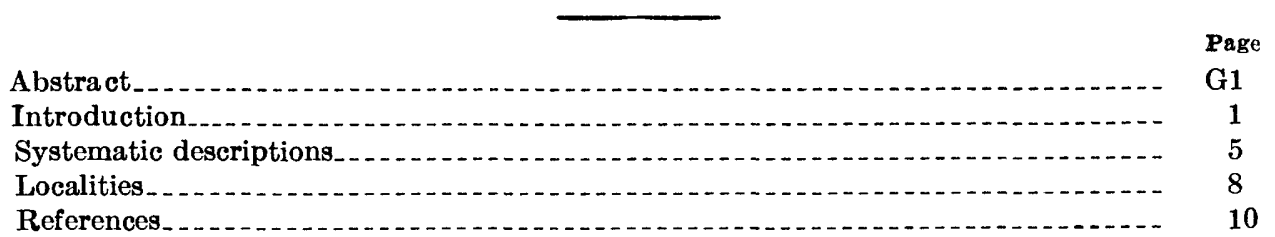

\section{ILLUSTRATIONS}

Prate 1. Codonofusiella laxa Douglass, n. sp.

[Plates follow text]

2-7. Monodiexodina kattaensis (Schwager):

2. From Kattha.

3. From Kafirkot.

4. Variability of this species in samples from West Pakistan.

5. Views of the tunnel area.

6. Variations in wall structure.

7. Variations in septal fluting and microspheric forms.

FIGURE 1. Index map showing fusulinid localities in the Salt and Khisor Ranges, West Pakistan.

2-6. Graphs showing measurements on Monodiexodina kattaensis (Schwager) from-

2. Samples $\mathrm{f} 23800$ and $\mathrm{f} 23793$; all attributes plotted against volution number

4. Combined samples; growth curves for the mean values superimposed at a radius of 0.3 mm

$0.3 \mathrm{~mm}$

5. Combined samples; all attributes plotted against the radius vector

6. Combined samples; frequency distribution of maximum prolocular diameters 



\title{
MORPHOLOGIC STUDIES OF FUSULINIDS FROM THE LOWER PERMIAN OF WEST PAKISTAN
}

\author{
By Raymond C. Doúglass
}

\begin{abstract}
A suite of samples from the Amb Formation in the Salt and Khisor Ranges of West Pakistan has yielded an abundance of fusulinids previously assigned to several species. There are many obvious differences between specimens and between samples in this suite. Traditional comparisons based on measurements at each volution support the idea that the visual differences are real : however, comparisons made at equal radii show great similarities between specimens and between samples. The differences are related to the size of the proloculus and are not considered sufficient evidence for specific discrimination; thus, these specimens are assigned to one species, Monodiexodina kattaensis.

A new species, Codonofusiella laxa, occurs in one of the samples with the larger fusulinids and represents the earliest known occurrence of this genus.
\end{abstract}

\section{INTRODUCTION}

The "Lower Productus Limestone" in the Salt and Khisor Ranges, West Pakistan, yields an abundant and well-preserved fauna of fusulinid Foraminifera. The fusulinids are all found in the Amb Formation of the Zaluch Group of Early Permian age as described by Teichert (1966). About 50 samples of the fusulinids, collected by R. E. Grant, U.S. Geological Survey, in 196465 , and Curt Teichert, Univ. Kansas, in 1966, contain the genus Monodiexodina, and one sample also contains the genus Codonofusiella.

Donald A. Myers of the U.S. Geological Survey was kind enough to send me many thin sections from Teichert's collections for use in this study. The samples collected by Grant were prepared by Richard Margerum of the U.S. Geological Survey. These collections were made as part of the cooperative U.S. Geological SurveyPakistan Geological Survey minerals investigations program sponsored jointly by the Agency for International Development, U.S. Department of State, and the Government of Pakistan. Two samples from the Salt Range, West Pakistan, were provided for comparison by John W. Skinner, of Humble Oil and Refining Com- pany. The localities for the samples studied are shown in figure 1 and are listed at the end of this report.

The fusulinids all seem to occur in a calcareous sandstone, some of which is micaceous. There is some variotion in the coarseness of the sand, but none of the detrital grains approaches the size of the fusulinids. The fusulinids show some abrasion and fracturing and aro somewhat size sorted, although immature forms and smaller fragments are found with adult specimens.

The presence of Codonofusiella associated with Monodiexodina is somewhat surprising, as Codonofusiella is commonly found in rocks assigned a Late Permian age with Polydiexodina or Yabeina. The rather primitive form described here extends the known range of the genus into the Early Permian.

Fusulinids were described from the "Productus Limestone" by Schwager (1887, p. 985-990). He assigned specimens to three named species and to one indeterminate species and suggested the possible existence of other subspecies. The species he described are from Katta (or Kattha), from Pail, and from a place he identified only as the Verala scarp, and he reported that specimens from Chidroo (or Chhidru) are similar to those from Kattha.

Dunbar (1933, p. 408-412) described specimens from near Warcha (or Warchha) and compared them with Schwager's descriptions and illustrations. He showet the striking similarity of his specimens to Fusulina kattaensis Schwager and to the illustrated specimens of $F$. pailensis Schwager. The abundant samples collected by Teichert and Grant present an opportunity to study the range of variability in the morphology of these fusulinids. For this purpose, over 700 thin sections were prepared and the customary measurements made. A preliminary report was presented by Douglass (1968).

Each sample of the fusulinids is relatively homogeneous in morphologic characters, and measured attri- 


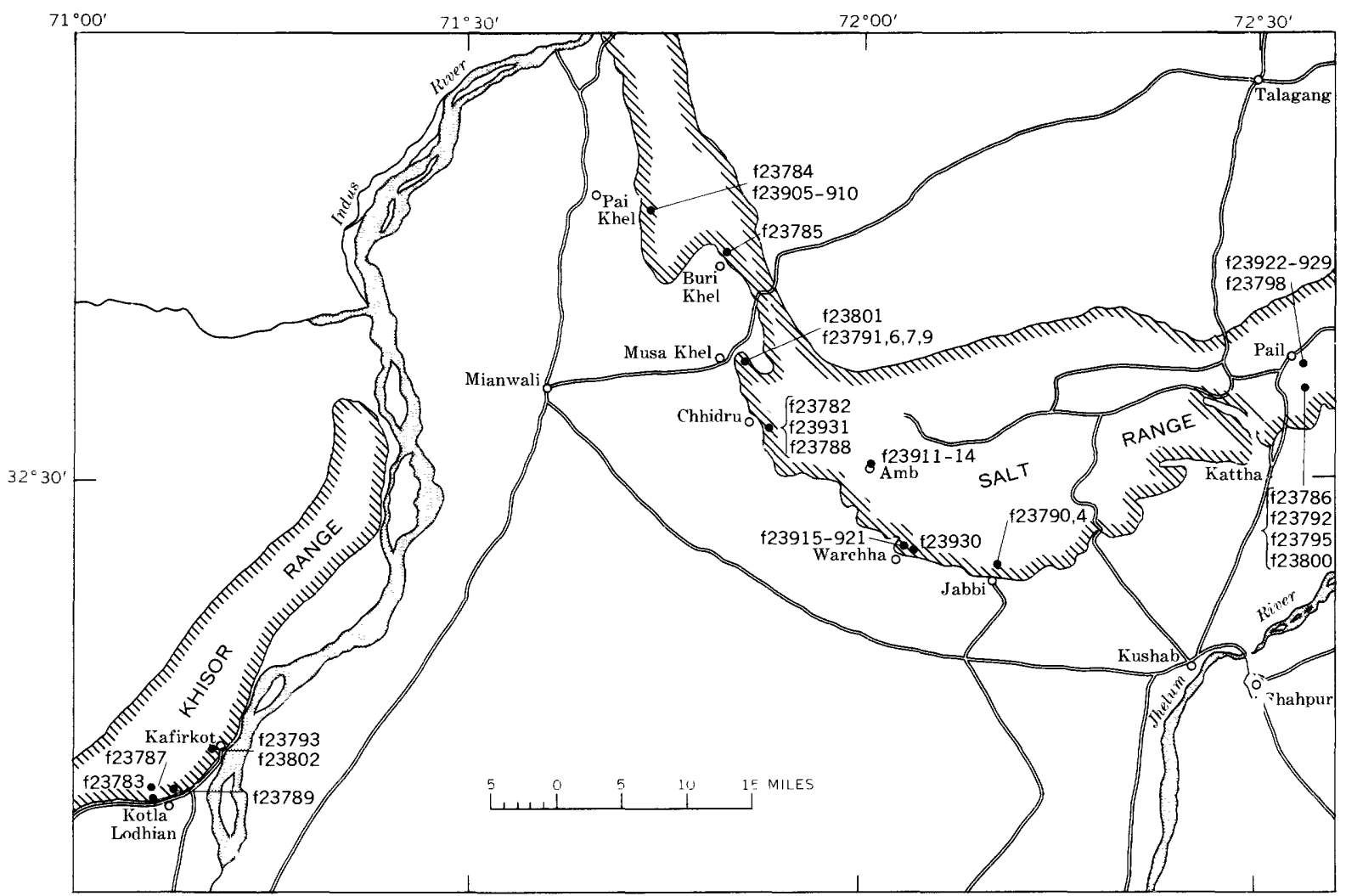

Frgure 1.-Fusulinid localities in the Salt and Khisor Ranges, West Pakistan. See section on localities for locality descriptions.

butes have a fairly normal distribution of values over a rather limited range. However, rather large differences in the dimensions of some attributes at specified volutions were found between many of the samples, and there was little or no overlap of measurement ranges. Using conventional methods for comparison, based on a few specimens or eren on reasonably large samples, statistically significant differences between samples could be demonstrated at certain volutions.

Two extremes will be compared, sample f23800 from Kattha and sample f23793 from Kafirkot. The specimens from Kattha (pl.2) have a mean prolocular diameter of about 160 microns, a tightly coiled juvenarium followed by more loosely coiled outer volutions, low intense septal fluting, and a little axial filling. They attain a maximum length of about $11 \mathrm{~mm}$.

The specimens from Kafirkot ( $\mathrm{pl} .3$ ) have a mean prolocular diameter of about 600 microns, regular and fairly open coiling, low intense septal fluting, and very little axial filling. They attain a maximum length of about $18 \mathrm{~mm}$.

Figure 2 shows the summary data for measurements made on specimens from these two samples plotted by volution. There is some overlap in the ranges of these attributes, but the means are well separated except in the form ratios. One should have no problem in distin- guishing these samples on the basis of prolocular diameter, wall thickness, volution height, sejtal count, or tunnel angle. Two "obviously" different and statistically separable "species" are represented. I place the quotes around the words "obviously" and "species" because I do not consider either one valid. The "obviously" is based on what we see in the illustrations Comparing plates 2 and 3, both showing the samples at similar magnifications, the differences in size are striking, and we have no trouble distinguishing the forms. It is, perhaps, more difficult to see the similarities because the size difference is dominant.

If we plot a growth curve of mean values for the radius vector at each volution against the volution, we find that the curves generated for both sumples can be superimposed (fig. $3 A$ ). This relation suggests that the growth pattern for both samples is similar and that the differences noted above may be a function of size. Because the initial size (prolocular diameter) averages about 160 microns in sample f23800 and about 600 microns in sample f23793, dimensions in the early volutions for specimens of sample $\mathrm{f} 23800$ will be smaller than for the early volutions for specimens of sample f23793. Dumbar and Skinner (1937, p. 541-543) discussed this problem and suggested that comparisons should not be made at the same numbered volutions but 
MORPHOLOGIC STUDIES OF FUSULINIDS FROM THE LOWER PERMIAN OF WEST PAKISTAN
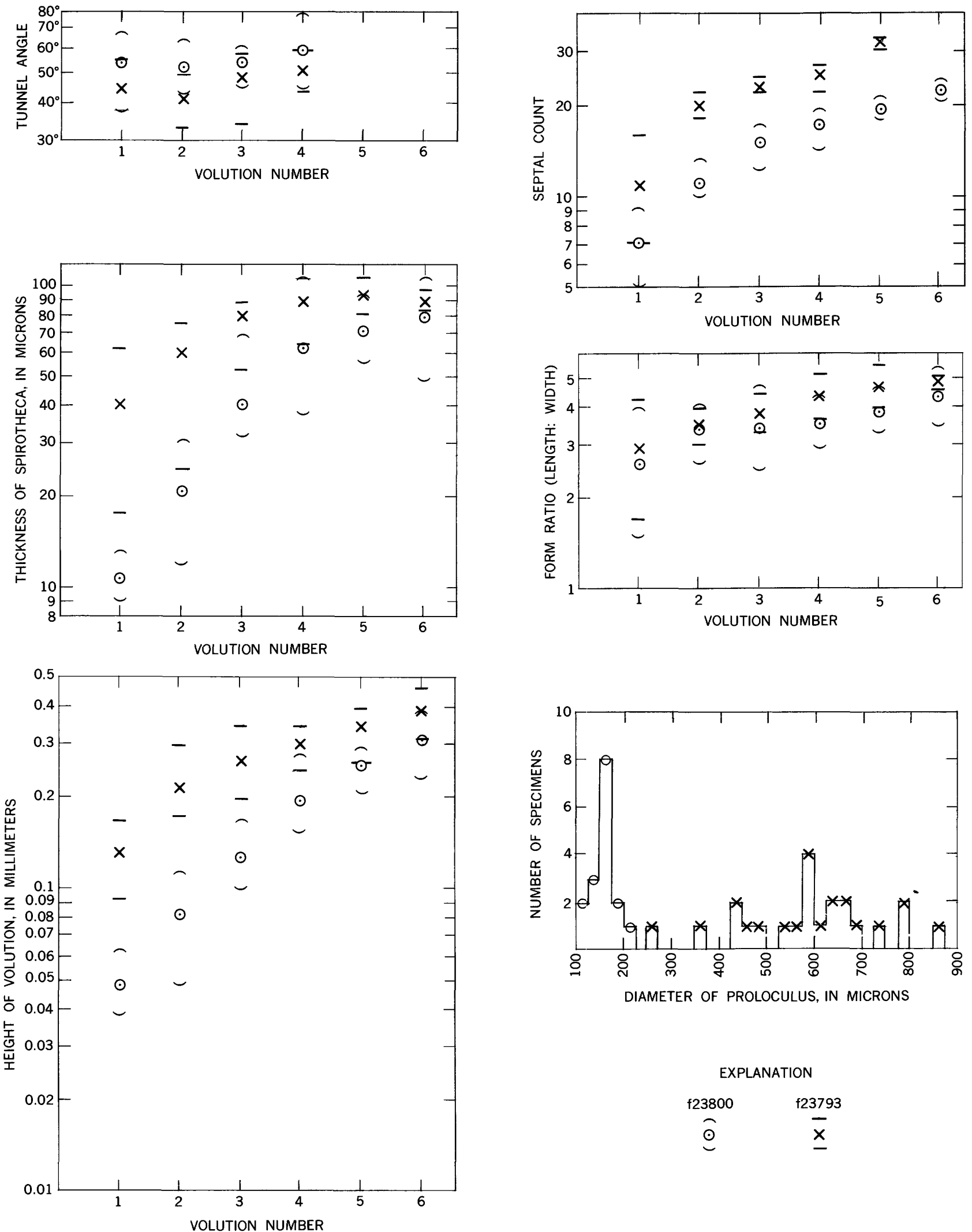

Figure 2.-Summary graphs for Monodiexodina kattaensis (Schwager) from samples f23800 and f23793; all attributes plotted against volution number. The mean and limits of observed variation are shown. 

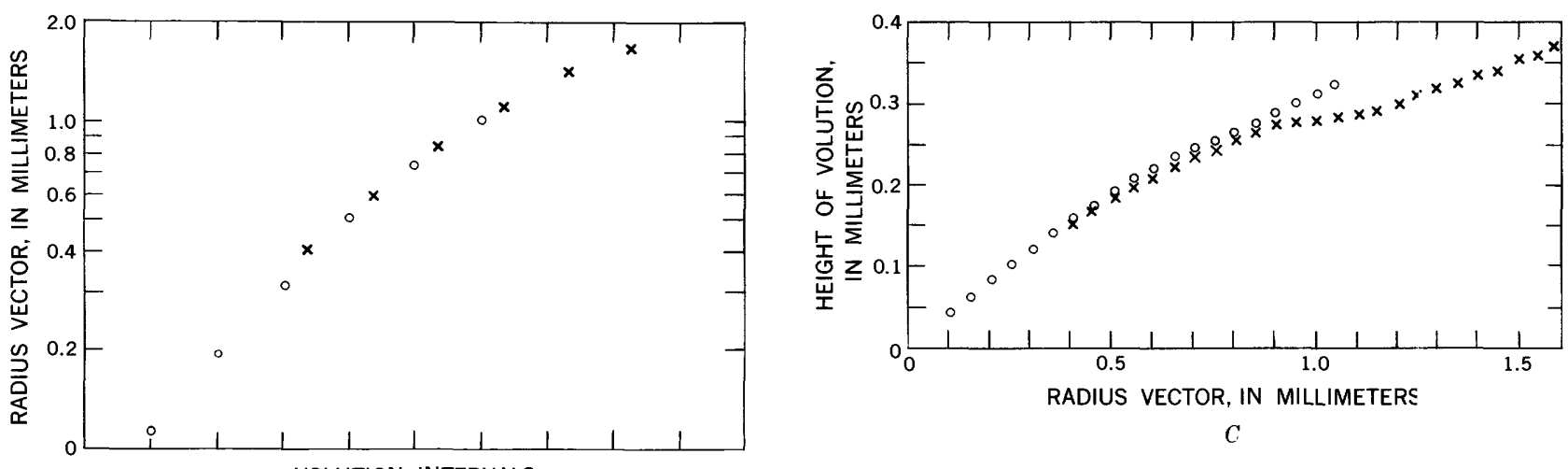

$A$

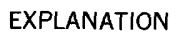

- $f 23800$

$\times\{23793$

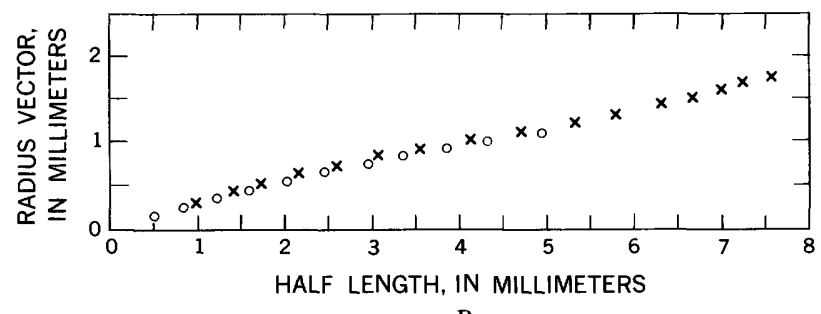

$B$

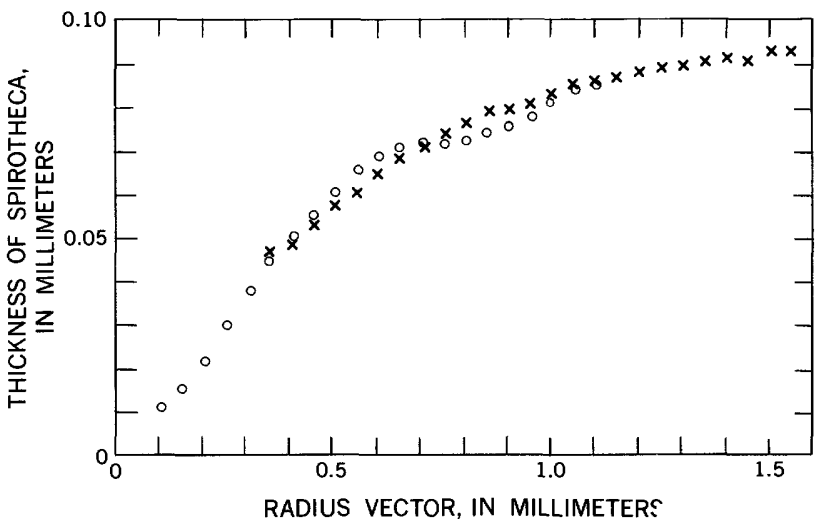

$D$

Figure 3.-Measurements on Monodiexodina kattaensis (Schwager) from samples f23800 and f23793; all attributes plotted against the radius vector. A. Growth curve for the mean values of the radius vector at each volution, plotted against volution intervals. $B-D$. Radius vector plotted against the half length $(B)$, the height of volution $(C)$, and wall thickness $(D)$. Curves show similar patterns for specimens from the two samples.

should be made at volutions of comparable size. This idea was further elaborated by Cutbill and Forbes (1967, p. 325-326), who demonstrated graphical methods for compensating for differences in prolocular size.

By plotting the radius vector directly against the half length, a growth curve can be generated for each specimen. The mean values for the two samples plot on essentially the same line (fig. $3 B$ ). When the volution height or the wall thickness are plotted against the radius vector, the curves generated for the mean values of the two samples again essentially superimpose (figs. $3 C . D$ ). It is, therefore, apparent that those two samples are similar in the measured attributes when they are compared at the same diameter (or radius) though they differ in size at their equivalent volutions.

These two samples were chosen for detailed study because they seem to represent opposite extremes of the observed variation among all the samples studied. Knowing that these two extremes are similar, one might expect the samples that are apparently intermediate also to be similar in the same attributes. The attributes for 15 additional samples were measured and plotted as individual samples, and then all measurements of each attribute were combined and the mean curves for all the data were plotted. Not surprisingly, the mean curves for the combined samples plot essentially on the same lines as the plots for either of the extreme samples. Thus, samples cannot be distinguished meaningfully on the basis of the data from these measurements.

Each sample differs somewhat from eve"y other sample, just as each specimen differs from every other specimen within the same sample. Nevertheless, attempts were made to find sets of samples that lave complete overlap in all attributes, but it was found that the sets included different groups of samples for each attributesimilarity cluster.

The entire range of variation can be likened to a spherical mass with radiating rays extending out from the sphere, each ray representing extremes of variation in a particular attribute. For example, sample f23798 is different from all the others in wall thickness, f23790 in form ratio, f23793 and $f 23800$ in volution height, f23794 in septal count, f23793 in axial flling. An attempt was made to relate the variability to stratigraphic position within the Amb Formation and to geographic 
location, but no correlation of morphology with the limited stratigraphy or with the geography was found.

The assumption is made that the variation in prolocular diameter is related to the life cycle of the fusulinids. Le Calvez (1953, p. 182-200) and others have shown that several megalospheric generations can develop between microspheric generations in the Foraminifera. The prolocular diameter of each succeeding megalospheric generation can be of a different size range so that a single species can be represented by a series of sexual and asexual generations that have widely divergent prolocular diameters. Therefore, on the basis of this assumption and the measurement data presented herein, these samples are assigned to one species, Monodiexodina kittaensis (Schwager).

The results of this study suggest that the descriptions and comparisons made in previous fusulinid studies should be reexamined. Undoubtedly many of the differences noted between samples or specimens are real, but it is also likely that many similarities ha re been masked by the methods of measurement-data presentation and by the optical illusion inherent in prolocular size differences. The measurement data obtained by conventional methods can be used for making comparisons at equal radii; so all previous studies that have presented enough measurement data can be reevaluated without great difficulty. Where only verbal descriptions, descriptions with minimal measurements, or summaries of measurements are given, more data will have to be assembled before meaningful comparisons can be made.

\section{SYSTEMATIC DESCRIPTIONS}

\author{
Family FUSULINIDAE von Möller, 1878 \\ Subfamily BOULTONIINAE Skinner and Wilde, 1954 \\ Genus Codonofusiella Dunbar and Skinner, 1937 \\ Codonofusiella laxa Douglass, new species \\ Plate 1, figures 1-21
}

Diagnosis.-Shell minute, first volutions at large angle to later volutions, last few chambers forming an uncoiled flared flange, septa weakly to irregularly fluted, single tumnel bordered by discontinuous chomata.

Description.-This minute species is small even for the genus, which is represented by unusually small forms for the fusulinids. The specimens coil irregularly, changing their axis of coiling about $90^{\circ}$ after one to two and a half volutions (pl. 1, figs. $4,7,20$ ). The first volution is lenticular, but as the plane of coiling rotates the axis becomes elongate and an ellipsoidal to fusiform shape is developed (pl. 1, figs. 13-15). After three to four rolutions the shells develop a flared flange at a sharp angle to the coil. The flange continues to grow for about 15 chambers and forms the greatest dimen-

375-325 O-70-2 sions on the specimens (pl. 1, figs. 1-5, 13, 15). The largest dimension on the coiled part of the shell is abo't half a millimeter along the axis. The largest flaredflange length measured was less than $1.2 \mathrm{~mm}$. The proloculus is spherical in most specimens. Fifty proloculi were measured, and of these nine were between 30 and 35 microns in diameter, 35 were between 36 and 45 microns, and six were between 46 and 56 microns. The spirotheca is thin, consisting of a tectum and clear diaphanotheca. The thickness of the spirotheca varios but measures about 13 microns through the outer parts of the shell. The thickness does not change significantly across the center of the shell but does thin at the poles. The septa are inward extensions of the spirotheca and consist of the tectum and a thinned diaphanotheca. The septa are plane near the top of each chamber, but are fluted near the base of the chambers and toward the inner surface of the flared part of the shell. No cuniculi were recognized, but the intensity of the fluting in some parts of the specimens suggests cuniculi might have developed near the base of the flare in some specimens (pl. 1, figs. 12, 18). A tunnel bordered by chomata is present in the fusiform part of the shell (pl. 1, figs. 6, $8,9,13,15)$ and seems to continue along the flare (pl. 1 , figs. $4,5,21$ ). The chomata are principally deposits on the lower edges of the septa in the tunnel area, but they are comnected as true chomata in parts of the shell (pl. 1, figs. 6,19 ). The deposits, possibly as pseudochomata, can be seen on the flared part in some of the specimens (pl. 1, figs. 4, 21). No axial filling is present.

Comparisons and remarks.-Codonofusiella laxa dces not closely resemble any species described previously, but it does show similarities to the type species, $C$. paredoxicu Iumbar and Skimner, 1937. $\dot{A}$ study of their type material, description, and illustrations shows that although their specimens are larger, the coiled part of the shell goes through the same stages in approximately the same ways. The flare on the type material is smallnr and shorter than on $C$. Zaxa. but the specimens illustrated by Skimmer and Wilde (1954, pl. 45, figs. 5-7) show a well-developed flare. The proloculus of $C$. paradoxicu is consistently larger than is common for that of $C$. Tux $u$. The described and illustrated specimens of $C$. preradoxicu have a range of prolocular diameter frcm 50 to over 60 microns, but so few specimens are reprosented that one camnot tell what the actual range for the type species might be. As noted above, the maximum prolocular diameter recorded for $C$. lax a does reach 50 microns, but only three of the 50 specimens measurad attained that size. Dunbar and Skinner (1937) did not find chomata in the type species. It is not clear whether the specimens illustrated by Skinner and Wilde (1954) show chomata; there is obvious secondary thickening 
of the septa in the vicinity of the tunnel, but these deposits may be pseudochomata. The septal fluting shown in the type species appears to be more regular, higher, and more intense especially in the inner volutionsthan that of $C$. laxa. In every way, C. laxa seems to be more primitive than $C$. paradoxica.

Distribution.- This species was found in only one sample (f23788) in the lower part of the Amb Formation associated with Monodiexodina kattaensis (Schwager).

Specimens studied.-Forty thin sections were prepared from this sample, including several hundred random sections of Codonofusiella. The prolocular diameters of 50 specimens were recorded, and other measurements were made on 20 specimens.

Designation of types.-The specimen illustrated on plate 1 in figures $12 \mathrm{a}$ and $12 \mathrm{~b}$ is designated the holotype. All other figured specimens are paratypes. All types are deposited in the U.S. National Museum (USNM). The assigned USNM numbers are given in the plate explanation.

\section{Subfamily SCHWAGERININAE Dunbar \& Henbest, 1930 Genus Monodiexodina Sosnina, 1956 \\ Monodiexodina kattaensis (Schwager) \\ Plates 2-7; text figures 2-6}

Fusulina kattaensis Schwager, 1887, p. 985-987, pl. 76, figs. 1-11, pl. 78 , fig. 4 .

Fusulina pailensis Schwager, 1887, p. 987-988, pl. 77, figs. 1-6. Fusulina longissima Möller of Schwager, 1887, p. 988-989, pl. 77, figs. 6-12, pl. 78, figs. 1-3.

Parafusulina kattacnsis (Schwager) Dunbar, 1933, p. 408-412, pl. 22, figs. $1-2 j$.

Diagnosis.-A small to medium-sized species, 10-12 and rarely $20 \mathrm{~mm}$ long, of five to seven volutions with an eighth volution developed rarely. The specimens are usually elongate and tend to be subcylindrical, and the ends of the shell are bluntly rounded. The early stages tend to be slightly inflated in the center and a little more pointed at the poles. Coiling is relatively even and tight throughout. The septa are tightly fluted forming cuniculi in the lower part of the chamber and are nearly straight in the upper part of the chamber. Axial filling is variable, being slight to heavy, but chomata are not developed. A single, relatively wide tunnel is developed. The wall is thin and composed of a tectum and keriotheca. Phrenotheca are developed irregularly in some specimens.

Description.-The spiral form developed by most specimens is normal-negative to negative. The mean growth curves of 17 individual samples are shown in figure 4 ; it can be seen that the expansion rate for the radius decreases in the outer volutions. That this relation is also shown by the pattern for increase in volution height can be seen in figure 5A. Corversely, the lengths of the specimens increase graduall- in the inner volutions and then more rapidly in the outer volutions. Figure $5 B$ shows rate of increase in length with increasing radius based on data for the combined samples. The small specimens, then, tend to have a smaller form (length to width) ratio than the large specimens. As the specimens grow larger they become more elongate and large specimens have a form ratio greater than four (fig. $5 C^{\prime}$ ). The longest specimen measured is slightly broken at one end, but has $20 \mathrm{~mm}$ preser'ed and may have been as much as $22 \mathrm{~mm}$ long originally.

The proloculus in the megalospheric forms varies in diameter from about 100 microns to nearly 900 microns. Microspheric juvenaria are rare and are not represented by adults of large size but were found in normal-sized specimens (pl. 4, figs. 13, 35). Most of the samples have medium to small proloculi with most of the specimens in the range of 125 to 400 microns in diameter (fig. 6). The prolocular diameters in any one sample tend to cluster in a fairly compact group which suggests that each sample represents only the variation within one generation.

The wall thickens rapidly through the early parts of the test, but the rate of thickening slows down as the test grows large, and some thinning occurs in the outer volutions of some specimens (fig. $5 D$ ). Fr m the maximum and minimum values, it can be seen that a fair amount of variability was recorded. Some of this variability may be related to measurement errc $r$ rather than to actual variability, as the wall thickness is affected by some solution in the equatorial area and also by thickening next to the septa. The recordet thicknesses are all equatorial. The wall tends to maintain its thick-

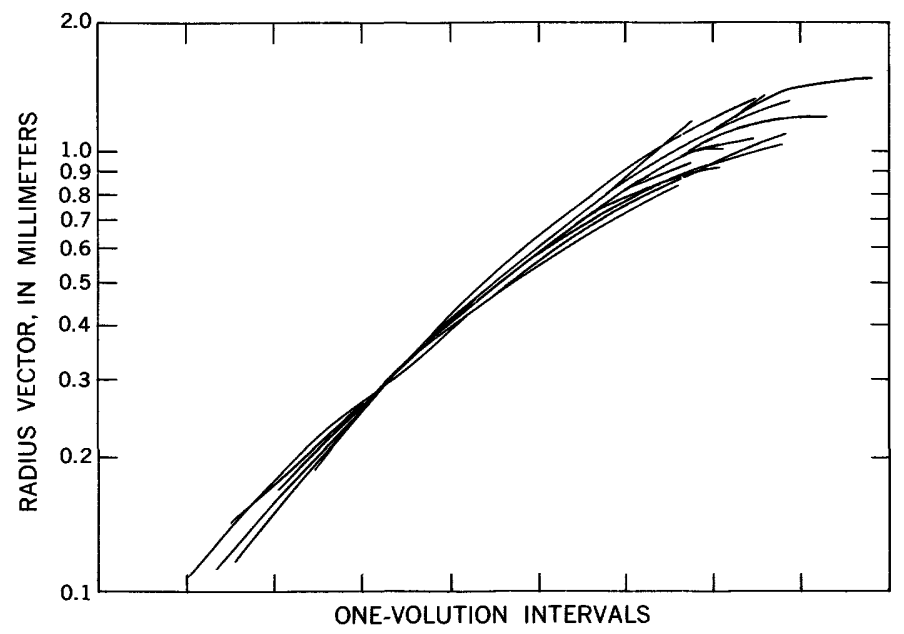

Figure 4.-Growth curves for the mean values of Monodiexodina kattaensis (Schwager) from 17 samples superimposed at a radius of $0.3 \mathrm{~mm}$. 
ness on the flanks out to a point where the wall starts to curve in to form the poles. In the polar area the confusion between outer wall and septal wall makes thickness measurements meaningless. The wall is composed of a tectum and fine to moderately coarse keriotheca. There is no apparent correlation between the coarseness of the keriotheca and other attributes. Many of the walls have straight and closely spaced alreoli (pl. 6, fig. 5). Others have more irregularly spaced alveoli, often with short bifurcations near the tectum (pl. 6, fig. 2). Phrenotheca are developed irregularly in some specimens (pl. 6, figs. $3,4,6$ ).

Figure $5 E$ shows the increase in number of septa with increasing diameter. The septa are not regularly spaced, and the arching of the chamber roof between septa exaggerates the spacing differences on some specimens. The septa are rather thick and often appear as bulbous masses in the tunnel area (pl. 6, fig. 1). They are nearly plane in the upper part of each chamber but are intensely fluted in the lower part; low cuniculi develop in most specimens ( pl. 7 , figs. 1-6). There is considerable rariation in the height to which fluting takes place within the chambers. Fluting extends to the top of the chamber in the poles of most specimens. In some specimens the higher fluting extends in toward the equatorial area. No systematic relationship seems to exist between the mature of fluting and other attributes of the test. Large septal pores are common in the polar area and in the outermost volutions (pl. 6, fig. 3).

The tunnel is well defined on most specimens and wanders only slightly in the meridional area. The height tends to be half to a little more than half the height of the volution. The width is rather variable. Figure $5 F$ shows that the tunnel angle decreases in the midvolutions and then increases to nearly $60^{\circ}$ in the larger specimens. An interesting feature of the tumnel area is the amount of resorption. Ordinarily, only the septa are resorbed to form the tumnel. Many specimens in these samples show resorption of the floor of the tumnel as well as of the septa. Plate 5, figures 1-5 are enlarged views of the resorption in equatorial and axial sections. As shown, the resorption occasionally remores most of the wall underlying the tumnel, and locally all of the wall is removed.

Axial filling is present in most specimens but is one of the most variable features of the species. Some specimens have massive deposits distributed along the entire axial zone; others have almost no axial filling, and others have deposits that are restricted to certain volutions (pl. 4). The distribution of axial filling is irregular within samples as well as between samples.
Comparisons and remarks. - The range of variability in the described specimens is sufficient to include all tro forms described by Schwager (1887) and by Dunbar (1933) from the "Lower Productus Limestone" of West Pakistan in this species. No group that would have ary significance stratigraphically or geographically could be separated from the rest of the specimens, and I doubt that any biologic differences exist within this group; the only differences appear to be those which exist, between different generations of the same species.

This species bears some resemblance to that describad as Schwagerina Tinearis by Dunbar and Skimner (19£7, p. 637), but the wall of $S$. linearis tends to be thicker at equivalent diameters; $S$. linearis is longer at equivalent diameters; and the septal fluting on $S$. linearis tends to extend higher on the septa and to be less inten'e along the base of the septa.

Monodiexodina bispatula Williams (1963, p. 33) shows considerable similarity to this species, but the wall of $M$. bispatula is consistently thinner at equivalent diameters. Schwagerina steinmanni of Dumbar and Newell $(1946$, p. 460$)$ is also similar but has a consistently thimner wall.

Thompson (1949, p. 189) redescribed Parafusulina wanneri (Schubert) from Timor and distinguished it from $M$. Kattaensis. $\mathrm{He}$ stated that $M$. kattaensis has more volutions at maturity, a thinner spirotheca (wall), and a smaller shell for corresponding volutions. $P$. wanneri is also more elongate and has form ratios of six to seven in the outer volution. Parafusulina shiptoni Dumbar (1940, p. 1) resembles $M$. kattaensis in many ways but tends to have a thinner wall in the midvolutions and is more elongate throughout. The septal fluting illustrated for P. shiptoni is also more intense than that commonly found in M. kattaensis. Dumbar (1940) considered P. shiptoni a more advanced form and therefore it should have a younger age than that represented by the "Lower Productus Limestone."

Designation of types.-Schwager (1887, p. 986) designated the specimens from the "upper region of the lower Productus-limestone of Katta and which have been represented in figures 1 and 2 of Pl. CXXVI" as typical. The figures desigmated are of whole specimens. His figures 1 to 5 are all indicated as being the same specias and his figures 3 to 5 are enlarged drawings of sections of the specimens. The specimen illustrated as a thin section in figure 3 of plate CXXVI (Schwager, 188i) is herein designated the lectotype and is included herein on plate 4 as figure 78, reduced to the same size as tr. other specimens for comparison. 


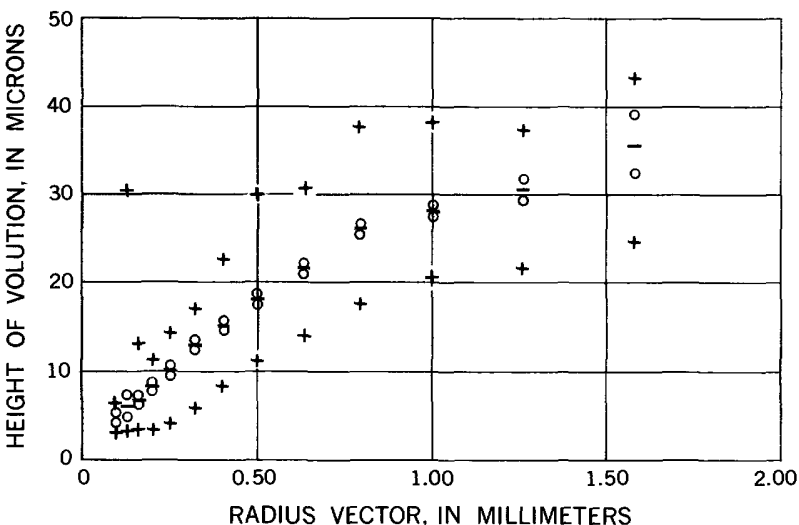

A

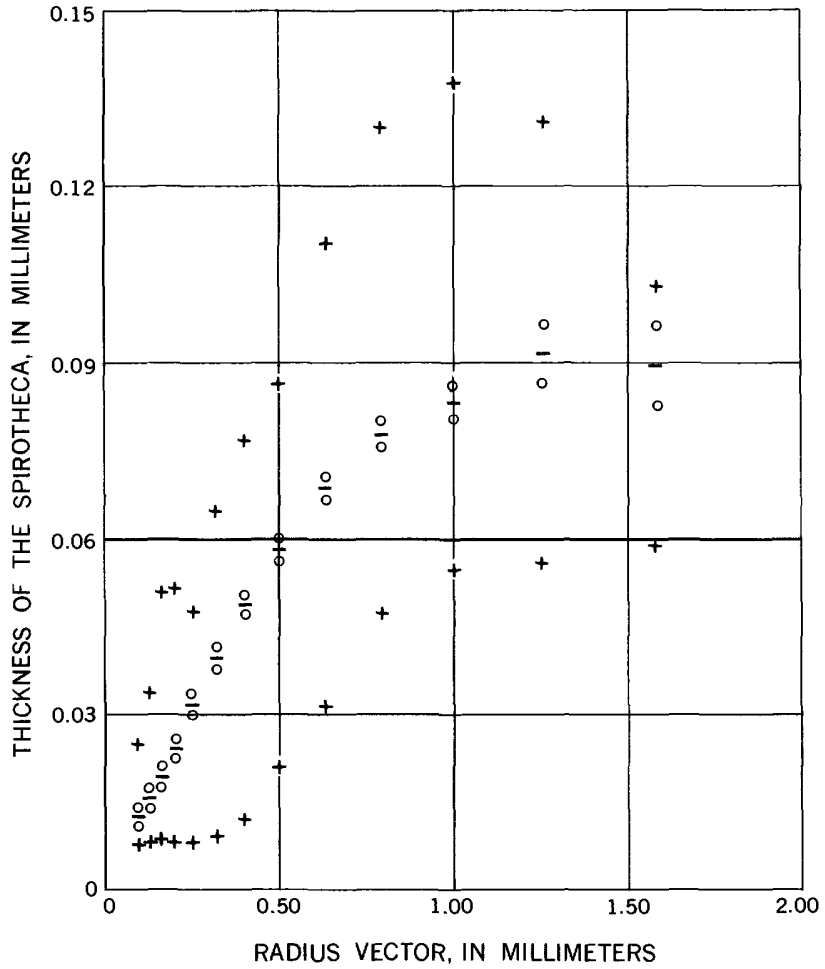

D

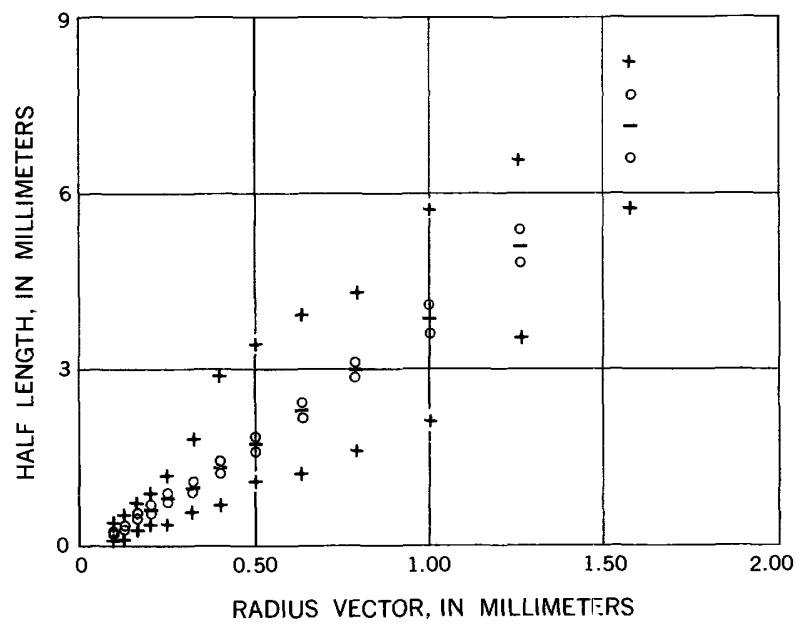

$B$

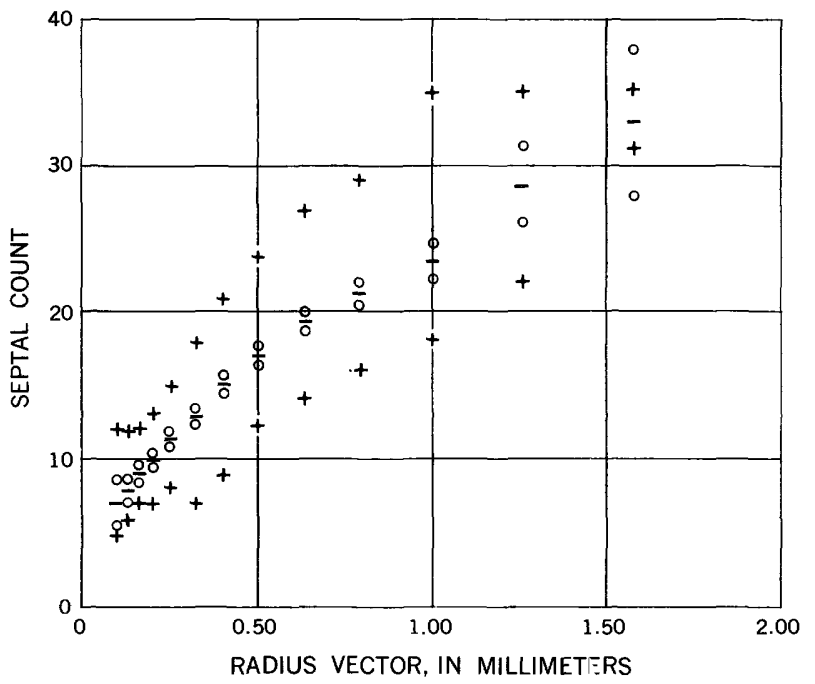

E

\section{EXPLANATION}

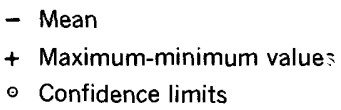

- Mean

- Confidence limits

Figure 5.-Measurements on Monodiexodina lattachsis (Schwager from the combined samples: all attributes rlotted against the radius vector. The mean, confidence limits of the mean, and the limits of observed variation are shown.

\section{LOGALITIES}

The general localities for the samples are shown in figure 1, based on the maps presented by Grant (1968, figs. 1, 2). More detailed locality information follows. The numbers used are U.S. Geological Survey Foraminifera catalog numbers that are used for the physical filing of the samples. The illustrated specimens are all separated and bear U.S. National Museum numbers that are given on the plate explanations.
Locality

f23782. Permian, Salt Range, Amb Formation, lower rusty bed on the south side of the small nala near Chbidru (at about lat $32^{\circ} 33^{\prime}$ N. : long $71^{\circ} 47^{\prime}$ E. ) : Pakistan Geol. Survey sheet No. 3S P/14. R. E. Grant, collector.

f23783. Permian, Khisor Range, Amb Formaticn, about $125 \mathrm{ft}$ above the base. About 1 mile north of Kotla Lodhian (at about lat $32^{\circ} 13^{\prime}$ N. ; long $71^{\circ} 04^{\prime}$ E.) ; Pakistan Geol. Survev sheet No. $38 \mathrm{P} / 4$. R. E. Grant, collector.

f23784. Permian, Salt Range, Amb Formation, lower $25 \mathrm{ft}$ of the formation in Zaluch Nala about 3.5 miles east of Pai 


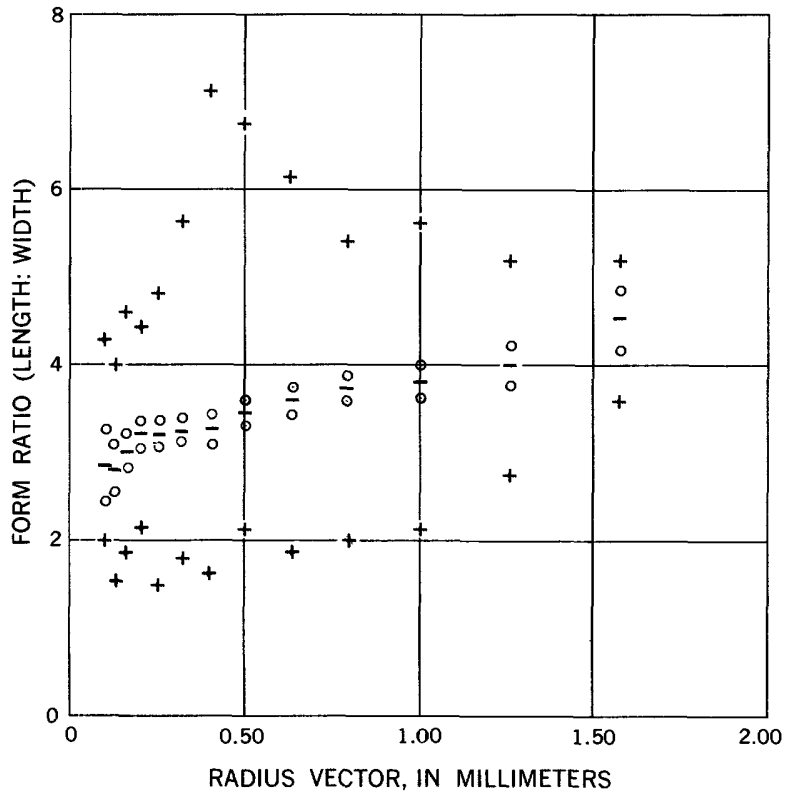

C

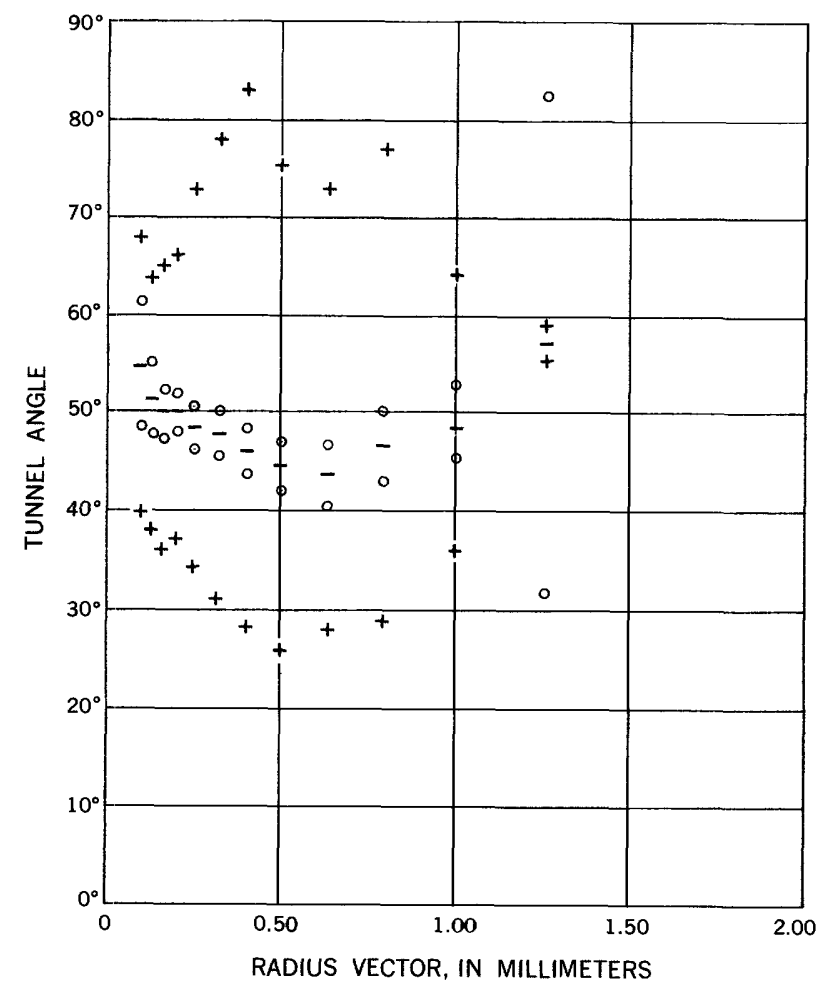

F

Khel (at about lat $32^{\circ} 47^{\prime}$ N.; long $71^{\circ} 38^{\prime}$ E.) ; Pakistan Geol. Survey sheet No. 38 P/9. R. E. Grant, collector.

f23785. Permian, Salt Range, Amb Formation, middle part in rusty-weathering ledges on the sharp ridge on the west side of Sarin Nala about 2.5 miles north-northwest of Buri Khel (at about lat $32^{\circ} 44^{\prime}$ N.; long $71^{\circ} 43^{\prime}$ E.) ; Pakistan Geol. Survey sheet No. 38 P/10. R. E. Grant, collector.

f23786. Permian, Salt Range, Amb Formation, lower part, about
$50 \mathrm{ft}$ below the rusty ledge in the section measured on the colliery road about 7 miles north-northeast of Kattha (at about lat $32^{\circ} 36^{\prime}$ N. ; long $72^{\circ} 29^{\prime}$ E.) ; Pakistan Geol. Survey sheet No. 43 D/6. R. E. Grant, collector.

f23787. Permian, Khisor Range, Amb Formation, about $25 \mathrm{ft}$ above the base and above the purple sandstone on the west side of the nala north of Kotla Lodhian near the entrarce and on the east side of hill 1301 (about lat $32^{\circ} 12^{\prime} \mathrm{N}$.; long $71^{\circ} 04^{\prime}$ E.) ; Pakistan Geol. Survey sheet No. 38 P/4. R. E. Grant, collector.

f23788. Permian, Salt Range, Amb Formation, $10 \mathrm{ft}$ of lirestone above the carbonaceous shale in Khan Zaman Nala about 2 miles east-southeast of Chhidru (at about lat $32^{\circ} 32^{\prime}$ N.; long $71^{\circ} 48^{\prime}$ E.) ; Pakistan Geol. Survey sheet No. 38 P/14. R. E. Grant, collector.

f23789. Permian, Khisor Range, Amb Formation, topmost san $7 y$ beds along strike in the arch of the anticline on the east side of the broad nala about 1 mile due north of Kotla Lodhian. The crest of the anticline is at an elevation of $1,283 \mathrm{ft}$ (about lat $32^{\circ} 13^{\prime}$ N. ; long $71^{\circ} 04^{\prime}$ E. ) ; Pakistan Geol. Surrey sheet No. 38 P/4. R. E. Grant, collector.

f23790. Permian, Salt Range, Amb Formation, below the rusty ledge on the slope across the nala from hill 1308 and 0.6 mile north of Jabbi (at about lat $32^{\circ} 24^{\prime} \mathrm{N}$.; long $72^{\circ} 06^{\prime} \mathrm{E}$ ) ; Pakistan Geol. Survey sheet No. 43 D/3. R. E. Grant, collector.

f23791. Permian, Salt Range, Amb Formation, about $8 \mathrm{ft}$ bel?w the first rusty ledge and from the indurated fusulinid $k$ sd in the middle of the ledge on a small ridge on the north edge of the mouth of Trimu Wahan, about 3 miles east of Musa Khel (at about lat $32^{\circ} 37^{\prime}$ N.; long $71^{\circ} 47^{\prime}$ E.) ; Pakistan Geol. Survey sheet No. 38 P/14. R. E. Grant, collector.

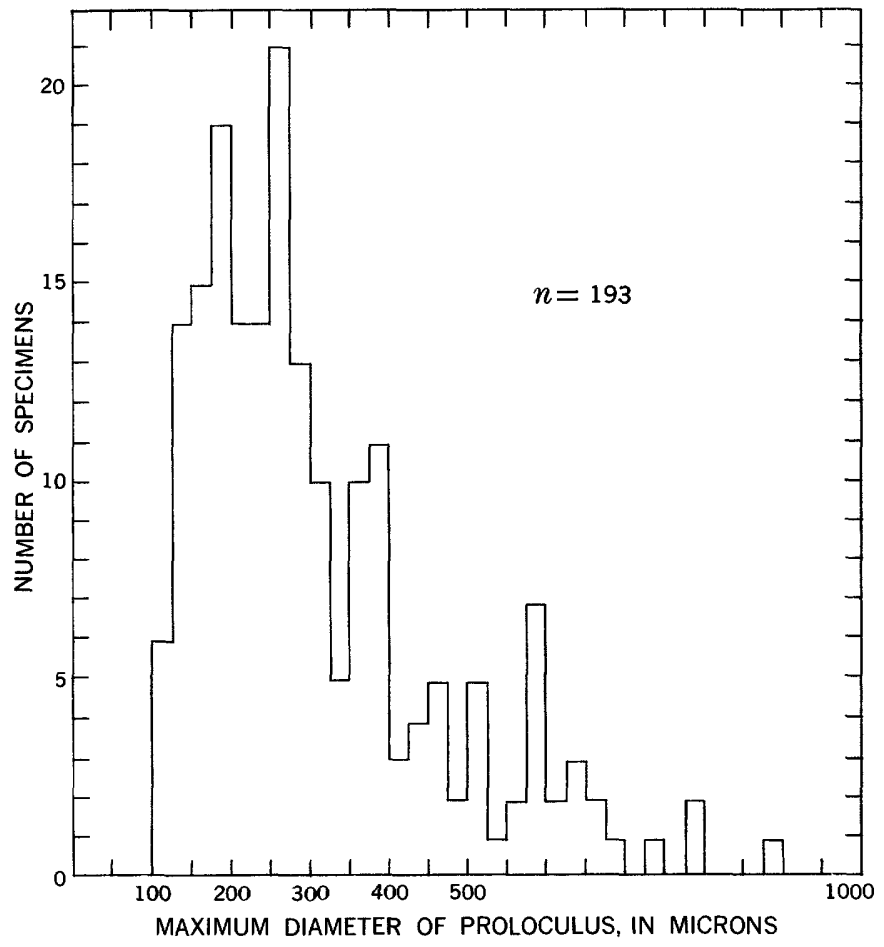

Figure 6.-Frequency distribution of maximum prolocular diameters for the combined samples of Monodicxodina kattacnsis (Schwager). 
f23792. Permian, Salt Range, Amb Formation, 20-30 ft below the rusty ledge in the same locality as f23786 near Kattha. R. E. Grant, collector.

f23793. Permian, Khisor Range, Amb Formation, ledges just west of Kafirkot (at about lat $32^{\circ} 14^{\prime}$ N.; long $71^{\circ} 09^{\prime} \mathrm{E}$.) ; Pakistan Geol. Survey sheet No. 38 P/4. R. E. Grant, collector.

f23794. Permian, Salt Range, Amb Formation, near locality f23790 but 0.5 mile to the north on hill 1813 about a mile north of Jabbi. R. E. Grant, collector.

f23795. Permian, Salt Range. Amb Formation; float along the colliery road in the vicinity of locality f 23786 north of Kattha. R. E. Grant, collector.

f23796. Permian, Salt Range, Amb Formation, below the rusty ledge in the vicinity of locality f23791, but about 0.2 mile to the north. R. E. Grant, collector.

f23797. Permian, Sait Range, Amb Formation, from just above the rusty dolomite beds on the low outliers just east of locality f23796. R. E. Grant, collector.

f23798. Permian, Salt Range, Amb Formation, rusty ledges 0.5 mile southeast of Pail (at about lat $32^{\circ} 38^{\prime} \mathrm{N}$.; long $72^{\circ} 28^{\prime}$ E.) ; Pakistan Geol. Survey sheet No. 43 D/6. R. E. Grant, collector.

f23799. Permian, Salt Range, Amb Formation, from the lower rusty ledge at locality f23796. R. E. Grant, collector.

f23800. Permian. Salt Range, Amb Formation, 5.4 ft below locality f23786 near Kattha. R. E. Grant, collector.

f23801. Permian, Salt Range, Amb Formation, just below locality f23796. R. E. Grant, collector.

f23802. Permian, Khisor Range, Amb Formation, in same ledges as locality f23793 west of Kafirkot. R. E. Grant, collector.

f23905. Permian, Salt Range, Amb Formation, $12 \mathrm{ft}$ above the base in the section measured in Zaluch Nala, about 3.5 miles east of Pai Khel at approximately the same location as locality f23784. Curt Teichert, collector. Field No. T62-35.

f23906. Permian, Salt Range, Amb Formation, same area and general horizon as locality f23905. Curt Teichert, collector. Field No. T62-260.

f23907. Permian, Salt Range, Amb Formation, $14 \mathrm{ft}$ above the base in the section measured in Zaluch Nala, same area as locality f23905. Curt Teichert. collector. Field No. T62-36.

f 23908 . Permian, Salt Range, Amb Formation, $20 \mathrm{ft}$ above the base in Zaluch Nala, same area as locality f23905. Curt Teichert, collector. Field No. T61-122.

f23909. Permian. Salt Range, Amb Formation, $29 \mathrm{ft}$ above the base in the section measured in Zaluch Nala, same area as locality f23905. Curt Teichert, collector. Field No. T62-38.

f23910. Permian, Salt Range, Amb Formation, $33 \mathrm{ft}$ above the base in the section measured in Zaluch Nala, same area as locality f23905. Curt Teichert, collector. Field No. T62-39.

f23911. Permian, Salt Range, Amb Formation, $67 \mathrm{ft}$ above the base: just north of Amb on Dhodha Wahan (at about lat $32^{\circ} 31^{\prime}$ N. ; long $71^{\circ} 56^{\prime}$ E. ) ; Pakistan Geol. Survey sheet No. $38 \mathrm{P} / 14$. Curt Teichert, collector. Field No. T62-321.

f23912. Permian, Salt Range, Amb Formation, $71 \mathrm{ft}$ above base in section at Amb, same area as locality f23911. Curt Teichert, collector. Field No. T62-322.

f23913. Permian, Salt Range, Amb Formation, 72-75 ft above base in section at Ainb, same area as locality f23911. Curt Teichert, collector. Field No. T62-323.

f23914. Permian, Salt Range. Anb Formation 83-91 ft above base in section at Amb, same area as locality f23911. Curt Teichert, collector. Field No. T62-325. f23915. Permian. Salt Range, Amb Formation, $\varepsilon .5 \mathrm{ft}$ above base of section in gorge about 1 mile upstream from Warchha salt mine (at about lat $32^{\circ} 27^{\prime}$ N.; long $71^{\circ} 57^{\prime}$ E.) ; Pakistan Geol. Survey sheet No. 38 P/15. Curt Te $e^{i s h e r t, ~ c o l l e c t o r . ~}$ Field No. T62-329.

f23916. Permian, Salt Range, Amb Formation, $13.5 \mathrm{ft}$ above base of section above Warchla, same area as locality f23915. Curt Teichert, collector. Field No. T62-330.

f23917. Permian. Salt Range, Amb Formation, 42-42.5 ft above base of section above Warchha, same area as locality f23915. Curt Teichert, collector. Field No. T62-334.

f23918. Permian. Salt Range, Amb Formation, 73-75 ft above base of section above Warchha, same area as locality f23915. Curt Teichert, collector. Field No. T62-339.

f23919. Permian, Salt Range, Amb Formation, $80 \mathrm{ft}$ above base of section above Warchha, same area as locality f23915. Curt Teichert, collector. Field No. T62-340.

f23920. Permian, Salt Range, Amb Formation, 87-89 ft above base of section above Warchha, same area as locality f23915. Curt Teichert, collector. Field No. T62-341.

f23921. Permian, Salt Range. Amb Formation, 92-93 ft above base of section above Warchha, same area as locality $\mathbf{2} 23915$. Curt Teichert, collector. Field No. T62-343.

f23922. Permian, Salt Range, Amb Formation, $80-85 \mathrm{ft}$ above base of a section measured immediately east and southeast of Pail, same area as locality f23798. Curt Teichert, collector. Field No. T62-365.

f23923. Permian, Salt Range, Amb Formation, 112-115 ft abore base of section at Pail, same area as locality f23798. Curt Teichert, collector. Field No. T62-367.

f23924. Permian, Salt Range, Amb Formation, 115-125 ft above base of section at Pail, same area as locality f23798. Curt Teichert, collector. Field No. T62-369.

f23925. Permian, Salt Range, Amb Formation, 153-156 ft above base of section at Pail, same area as locality f23798. Curt Teichert, collector. Field No. T62-370.

f23926. Permian, Salt Range, Amb Formation, 205-217 ft above base of section at Pail, same area as locality f23798. Curt Teichert, collector. Field No. T62-371.

f23927-f23929. Permian, Salt Range, Amb Formation, from uncertain position within the section at Pail, same area as locality f23798. Curt Teichert, collector. Field Nos. T62-362 to T62-36t.

f23930. Permian, Salt Range, "Lower Productus Limestone" (Amb Formation), $50 \mathrm{ft}$ above the base, near Warchha. (Probably the same area as locality f23:15) India Geol. Survey Collection No. K25/498. This is part, of the material studied by Dunbar in 1933.

f23931. Permian, Salt Range, Amb Fornation, near Chhidru (at lat $32^{\circ} 34^{\prime} 34^{\prime \prime}$ N. ; long $71^{\circ} 46^{\prime} 26^{\prime \prime}$ E.) ; Pakistan Geol. Survey sheet No. 38 P/14. Probably the same area as locality f 23782 . M. H. Kahn, collector.

\section{REFERENGES}

Cutbill, J. L., and Forbes, C. I., 1967, Graphical aids for the description and analysis of variation in fusuline Foraminifera: Palaeontology, v. 10, pt. 2, p. $₹ 22-337,13$ text figures.

Douglass, R. C., 1968, Morphologic studies of fusulinids from Lower Permian of West Pakistan [abs.] : Am. Assoc. Petroleum Geologists Bull., v. 52, no. 3, p. 525.

Dunbar, C. O., 1933, Stratigraphic significance of the fusulinids of the Lower Productus Limestone of the Salt Range : India, Geol. Survey Recs., v. 66, part 4, p. 405-413, pl. 22. 
1940, Permian fusulines from Karakoram: India, Geol. Survery Recs., v. 75, Prof. Paper 5, p. 1-5, pl. 1.

Dunbar, C. O. and Henbest, L. G., 1930, The fusulinid genera Fustilina, Fusulinclla, and Wedekindellina: Am. Jour. Sci., ser. 5, v. 20, p. 357-364.

Dunbar, C. O. and Newell, N. D., 1946, Marine Early Permian of the central Andes and its fusuline faunas: Am. Jour. Sci., v. 244, no. 7, p. 457-191, pl. 1-12.

Dunbar, C. O. and Skinner, J. W., 1937, Permian Fusulinidae of Texas: Texas Univ. Bull. 3701, p. 517-825, pl. 42-81, fig. 89-97.

Grant, R. E., 1968, Structural adaptation in two Permian brachiopod genera, Salt Range, West Pakistan: Jour. Paleontology, v. 42, no. 1, p. 1-32, pl. 1-9, 21 text figures.

Le Calvez, Jean, 1953, Ordre des Foraminiferes, in Grasse, P. P., 1953, Traite de Zoologie, Anatomie, Systematique, Biologie, Paris, Masson \& Cie v. 1; p. 149-265, fig. 107-181.

Möller, v. von, 1878, Die spiral-gewundenen Foraminiferen des russischen Kohlenkalks: Acad. Imp. Sci. St. Petersburg, Mem., ser. 7, v. 25, no. 9, p. 1-147, pl. 1-15, 6 fig.
Schwager, Conrad, 1887, Sub-Kingdom-Protozoa, in Waag?n, William, 1887, Salt-Range fossils : Palaeontographica Indi`a, ser. 13, v. 1, p. 983-994, pl. 76-78.

Skinner, J. W., and Wilde, G. L., 1954, The fusulinid subfamily Boultoniinae: Jour. Paleontology, v. 28, no. 4, p. 434-44, pl. $42-45$.

Sosnina, M. I., 1956, The genus Ussuriella, gen. nov., and the genus Monodicxodina, gen. nov., in Kiparisova, L. D., 1C56, [Contributions to paleontology-new families and genera]: Vses. Nauchno-Issled. Geol. Inst. Trudy, n.s., Paleo., v. 12, p. 21-29, pl. 4-7.

Teichert, Ourt, 1966, Nomenclature and correlation of the "Permian Productus Limestone," Salt Range, West Pakistan : Pakistan Geol. Survey Recs., v. 15, pt. 1, p. 1-20.

Thompson, M. L., 1949, The Permiam fusulinids of Timor: Jour. Paleontology, v. 23 , no. 2, p. 182-192, pl. 34-36, 1 text figure.

Williams, T. E., 1963, Fusulinidae of the Hueco Group (lower Permian), Hueco Mountains, Texas: Yale Univ. Peabady Mus. Nat. History Bull. 18, 123 p. 
PLATES 1-7 


\section{PLATE 1}

Figures 1-21. Codonofusiella laxa Douglass, n. sp. (p. G5). From locality f23788 in the lower part of the Amb Formation, West Pakistan.

1-5. Equatorial and subequatorial sections showing the development of the flange. Note the irreg'lar path of the flange and the irregular development of basal chamberlets. Figures 3 and 4 . show some pseudocr omata, and the section in figure 5 seems to cut the middle of the tunnel without touching the secondary deposits. All $\times 50$, except figure $4 \mathrm{~b} \times 100$. USNM 688167-171.

6. Section tangential to the outer coiled volution and the flange, showing chomata in the outer volution and straight septa in the flared flange. $\times 50$. USNM 688172 .

7. Oblique axial section cutting the inner volutions in the equatorial plane. $\times 50$. USNM $68817 \AA$.

8. Axial section cutting the inner volutions and the outer volutions in the axial plane but at right angles to each other and showing the tumnel and chomata. $\times 50$. USNM 688174.

9. Axial section oriented as in figure $8 . \times 100$. USNM 688175 .

10,11 . Sections cutting the flange at an oblique angle and showing the more complex fluting of the lower parts of the septa. $\times 50$. USNM 688176 and 688177 .

$12 \mathrm{a}, \mathrm{b}$. Axial section of the holotype, showing the inner volution at right angles to the outer volutions and a tangential slice obliquely through the flange. $\times 50$ and $\times 100$. USNM 688178 .

13. Axial section through the coiled part of the shell and a start of the flange. $\times 100$. USNM 688179 .

14. Near-axial section showing nearly right-angle change in coiling plane. $\times 100$. USNM 688180 .

15. Axial section of coiled part of the shell. $\times 100$. USNM 688181.

16. Near-axial section with inner volution cut in the equatorial plane. $\times 100$. USNM 688182 .

17. Axial section with inner volution in the equatorial plane, showing the beginning of the flange. $\times 100$. USNM 688183.

18. Axial section cutting through part of the flange. $\times 100$. USNM 688184.

19. Tangential section of the outer coiled volutions and part of the fiange, showing nearly straight septa and the chomata. × 100. USNM 688185.

20. Axial section with early volutions in the equatorial plane. $\times 100$. USNM 688186 .

21. Equatorial section with inner volution in the axial plane, showing the first part of the flange and part of the tunnel bordered by pseudochomata. × 100. USNM 688187. 
GEOLOGICAL SURVEY
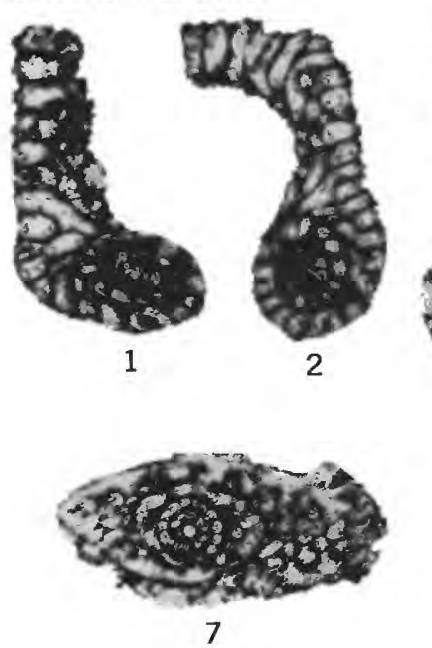

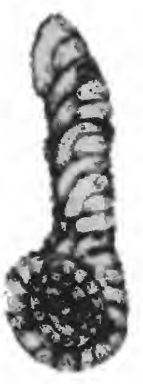

3

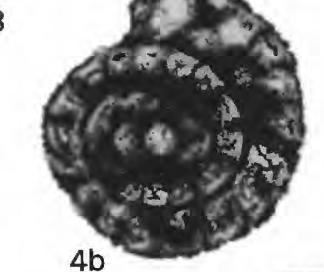

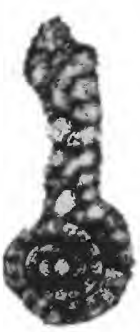

$4 a$

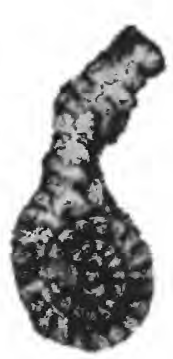

5

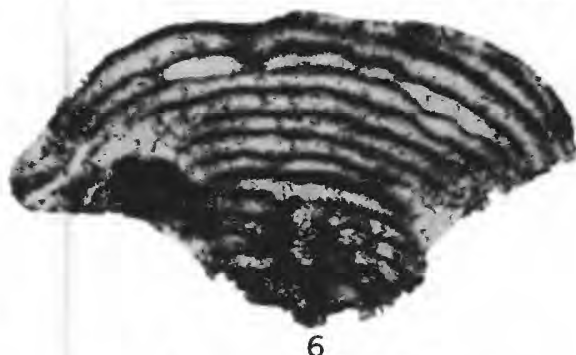

6
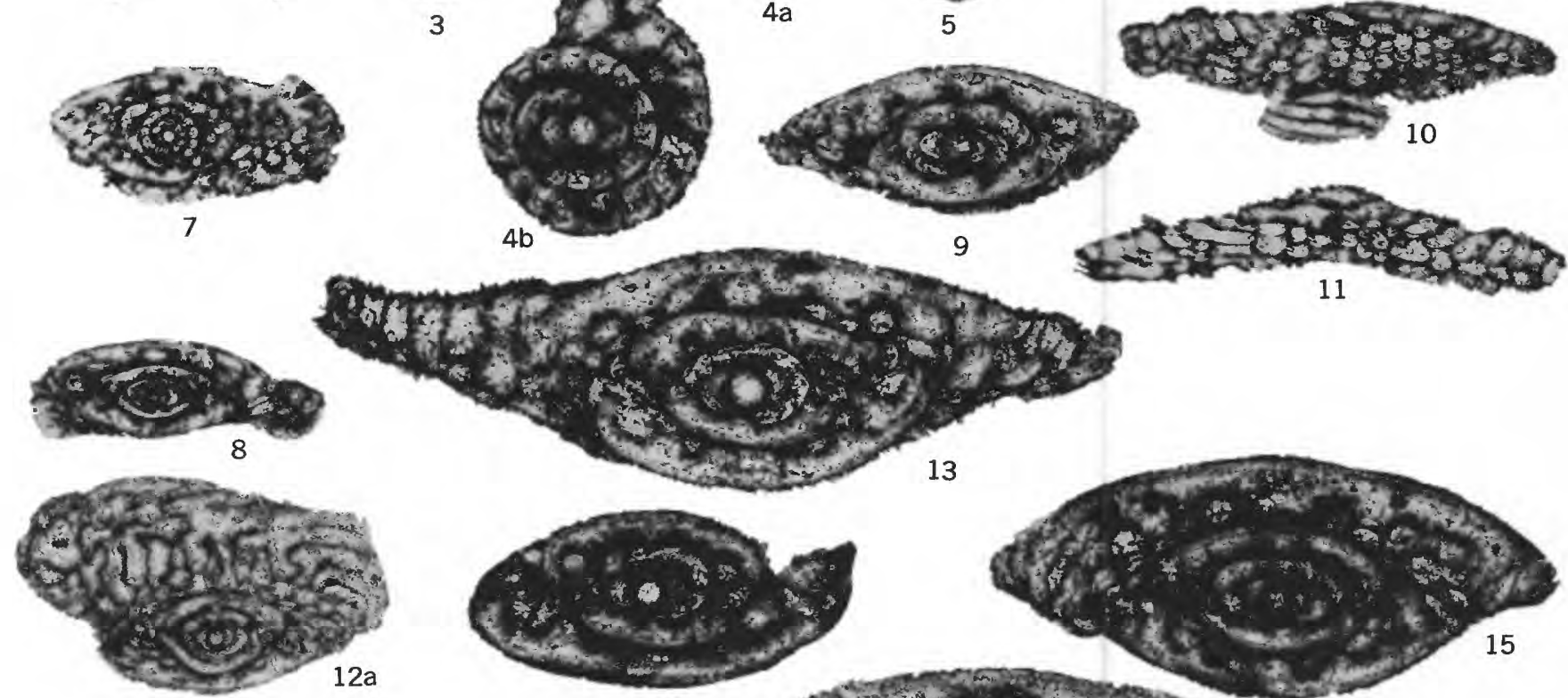

17n

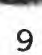

.

11
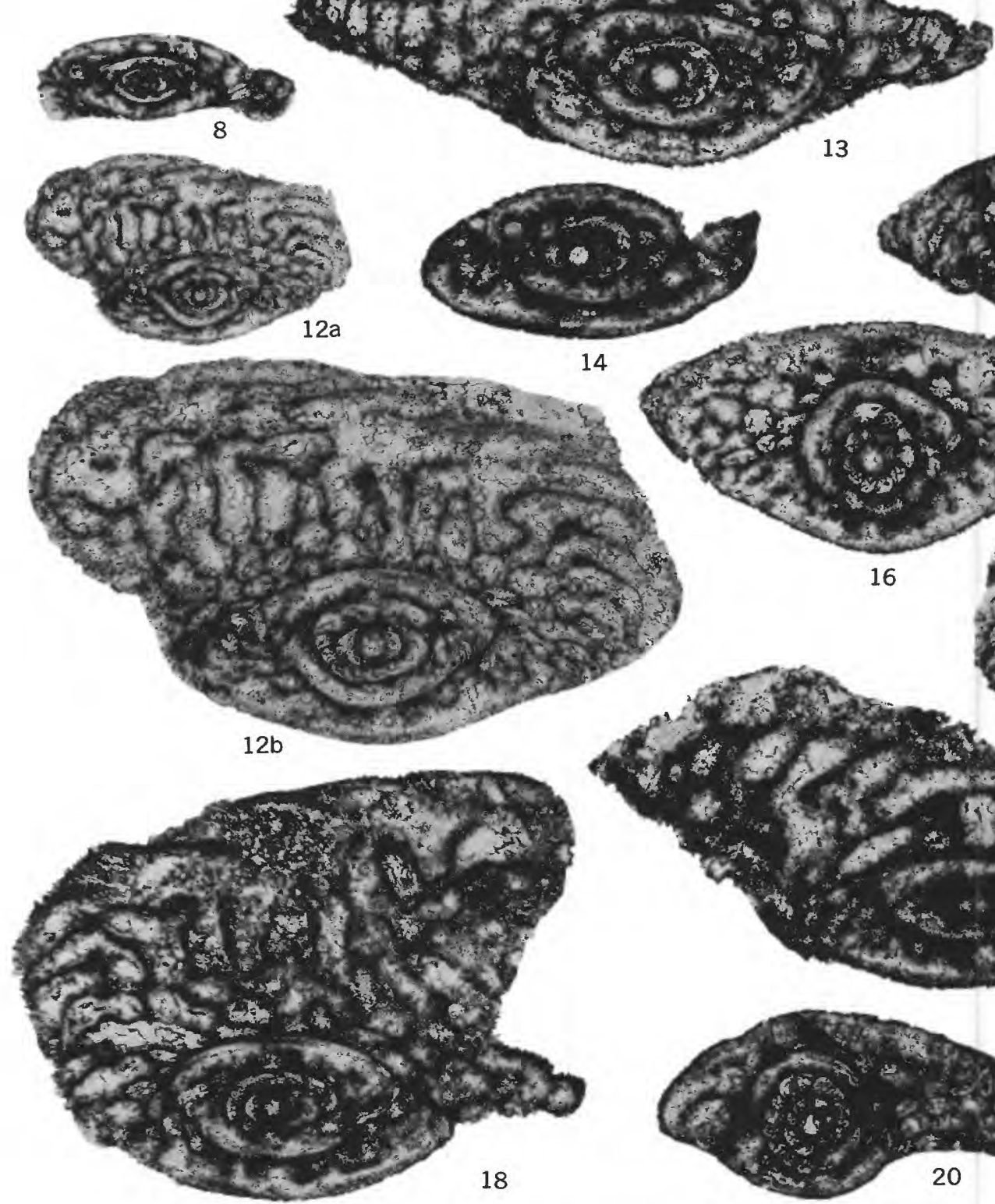

14
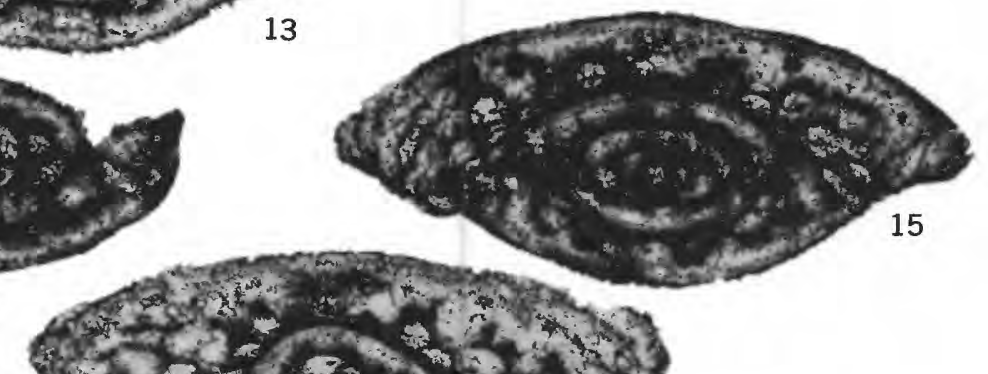

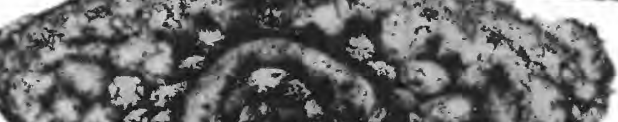

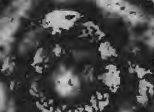




\section{PLATE 2}

[All figures $\times 10$, except 16 and $17, \times 50$ ]

Figures 1-17. Monodiexodina kattaensis (Schwager) (p. G6).

All from locality $\mathrm{f} 23800$ at Kattha, West Pakistan.

1. Axial section of one of the largest specimens found in this sample. The outermost volution is partly broken away from the specimen. This specimen also appears on plate 4, figure 52. USNM 688188.

2. Equatorial section of a complete specimen. Note the thinning of the spirotheca in the last few chambers and the nearly uniform tunnel height. USNM 688189.

3. Equatorial section. USNM 688190.

4. Axial section. This specimen also appears on plate 4, figure 56. USNM 688191.

5. Equatorial section. USNM 688192.

6. Equatorial section. USNM 688193.

7. Equatorial section. USNM 688194.

8. Axial section with almost no axial filling evident. USNM 688195.

9. Axial section. USNM 688196.

10. Tangential section showing nearly straight septa toward the top of the chamber and intensely fluted septa toward the bottom of the chamber on the right. USNM 688197 .

11. Tangential section showing intensely fluted septa and a cuniculus. USNM 688198 .

12. Axial section. USNM 688199.

13. Axial section. This specimen also appears on plate 4, figure 77. USNM 688200.

14. Axial section. USNM 688201.

15. Axial section. USNM 688202 .

16. Enlarged view of figure 12, showing wall structure and some solution of the wall in the tunnel area.

17. Enlarged view of figure 15. Note the solution in the tunnel area in the third and fourth volutions on the lower side. 

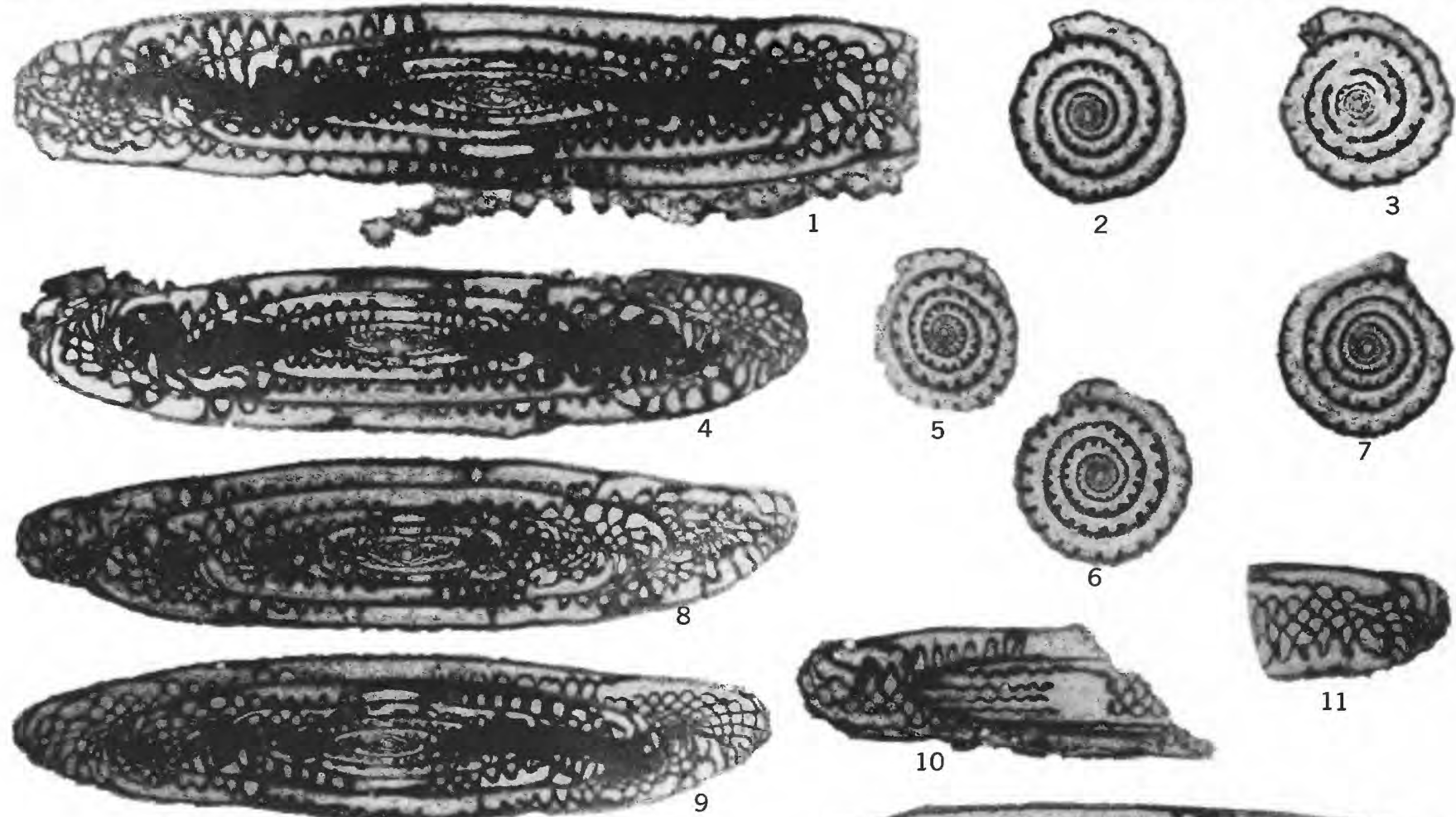

11
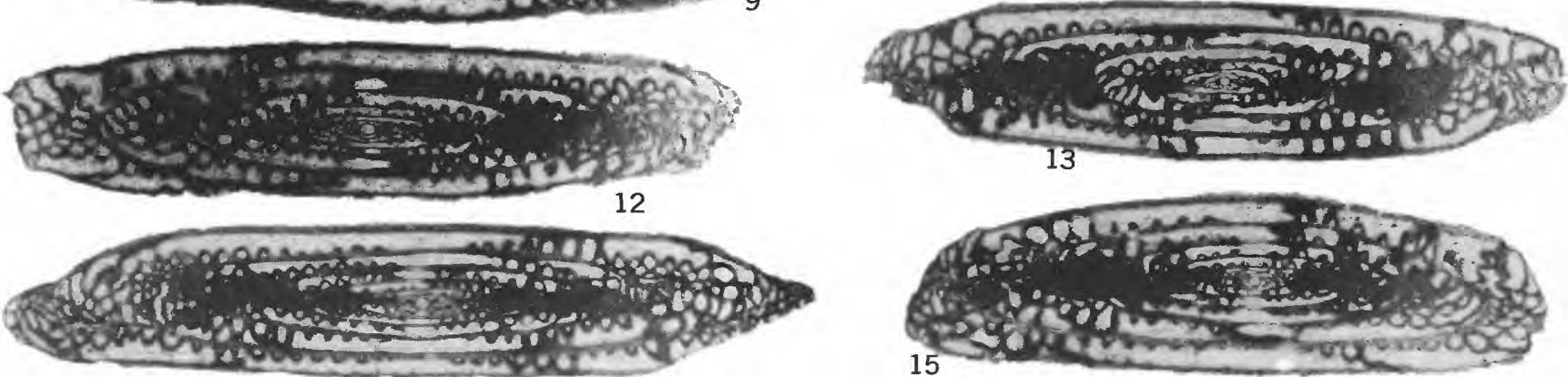

14
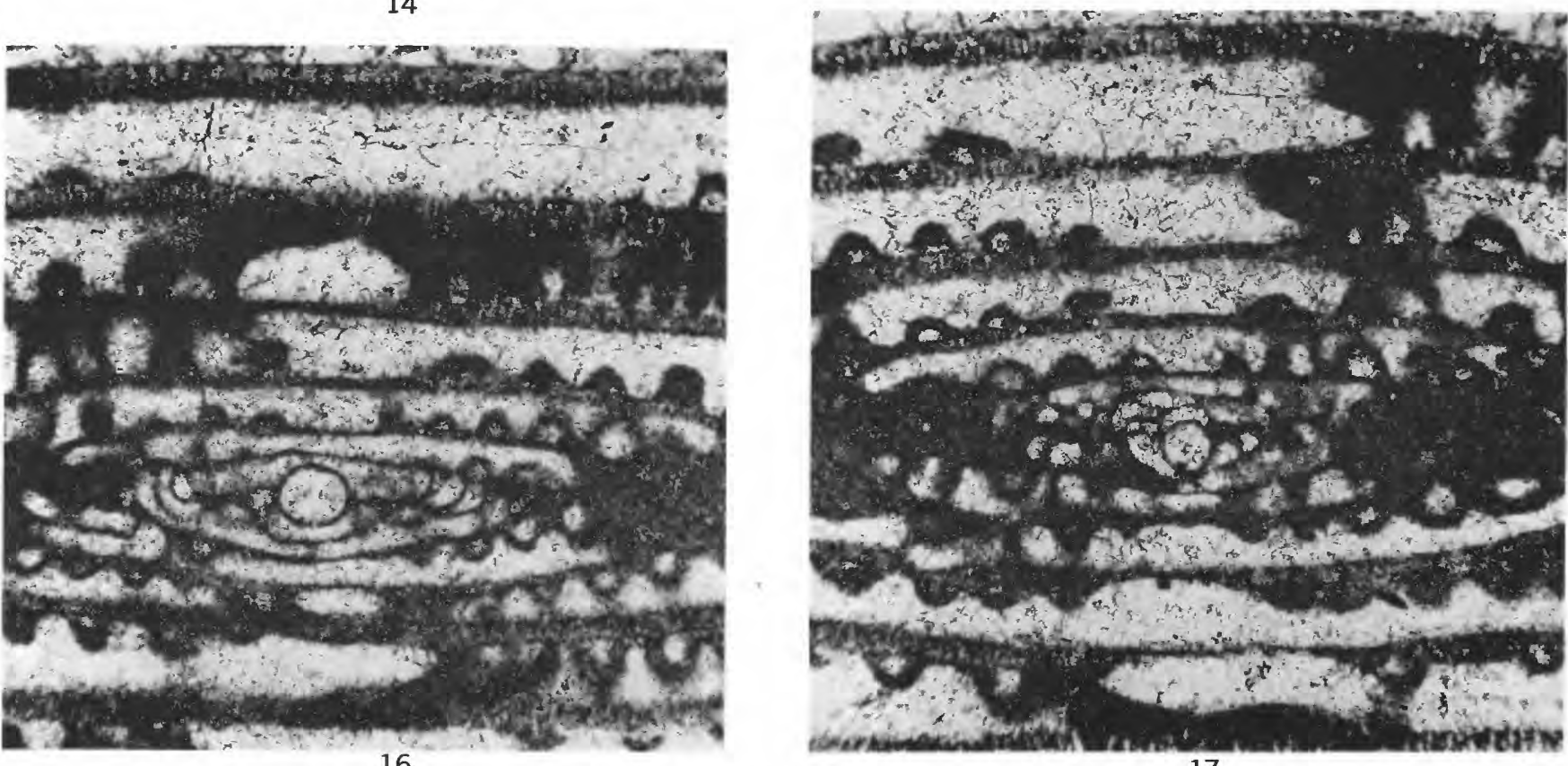

MONODIEXODINA KATTAENSIS (Schwager) from Kattha 


\section{PLATE 3}

[All figures $\times 10$, except figure $8, \times 50$ ]

Figures 1-8. Monodiexodina kaltaensis (Schwager) (p. G6). All from locality f23793, Kafirkot, West Pakistan.

1. Equatorial section showing some distortion in the outer volution. USNM 688203.

2. Axial section of one of the best preserved large specimens with large proloculus. An enlarged view of this specimen is shown on plate 5 , figure 1 , and the specimen is shown in relation to the total sample on plate 4, figure 4. USNM 688204.

3. Equatorial section. USNM 688205.

4. Fractured axial section. USNM 688206.

5. Equatorial section showing the wall considerably thinned by solution in some of the volutions. USNM 688207.

6. Slightly oblique axial section. USNM 688208 .

7. Tangential section showing complete transition from nearly straight septa in the upper part of the chambers to cuniculi at the base. USNM 688209.

8. Enlarged view of figure 3 , showing the wall structure. 
GEOLOGICAL SURVEY

PROFESSIONAL PAPER 643 G PLATE 3
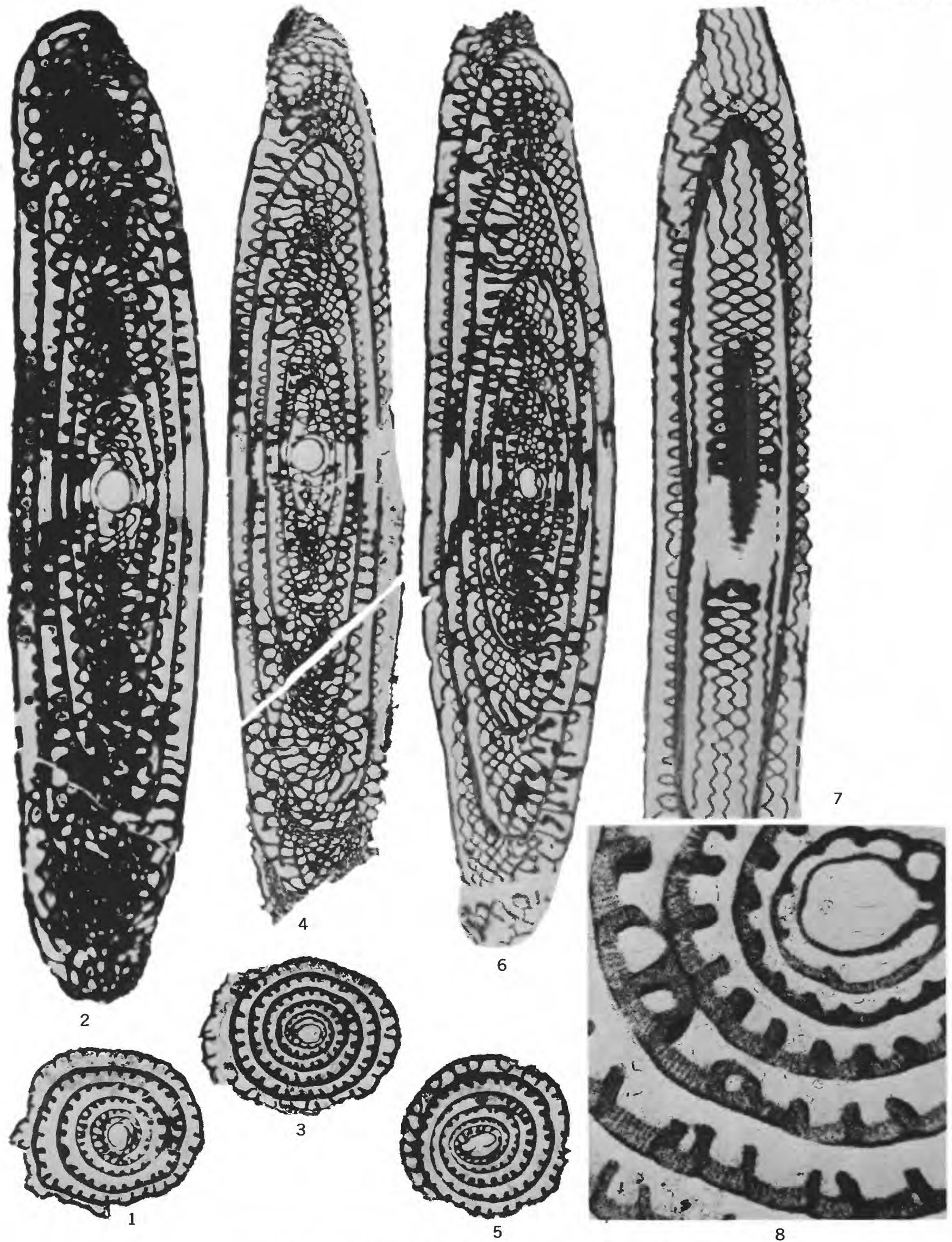

MONODIEXODINA KATTAENSIS (Schwager) from Kafirkot 


\section{PLATE 4}

[All figures $\times 5$ ]

Figures 1-82. Monodiexodina kattaensis (Schwager) (p. G6).

This plate shows the range of variability found in this species in the samples studied from West Pakistan. The specimens are arranged arbitrarily; the forms that have small megalospheric proloculi are toward the bottom and the forms that have large megalospheric proloculi toward the top. The more elongate forms tend to be along the left side and the more ellipsoidal forms toward the right. Specimens illustrated by Schwager as Fusulina kattaensis, Fusulina pailensis, and Fusulina longissima are included at the same magnification for direct comparison.

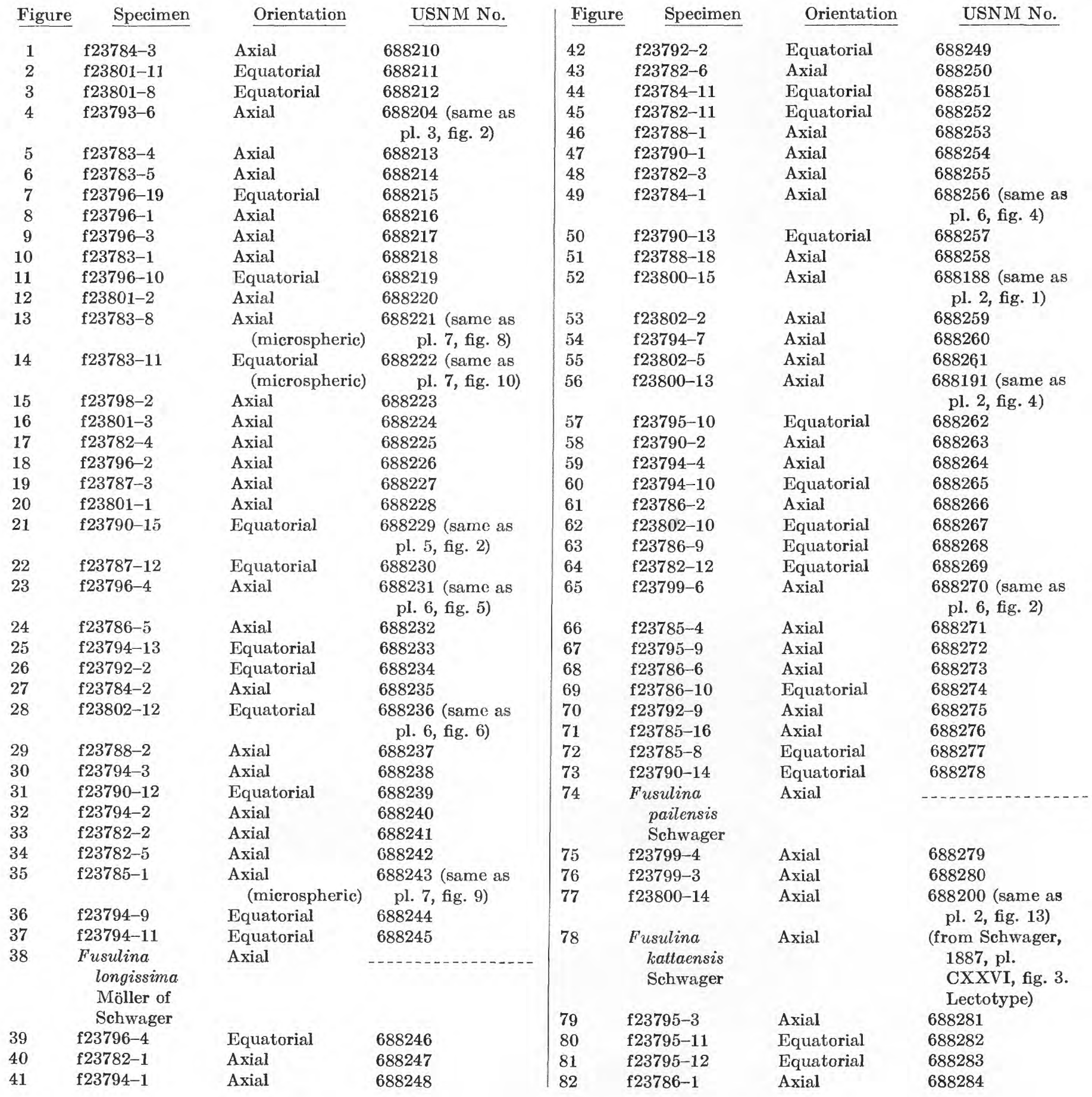



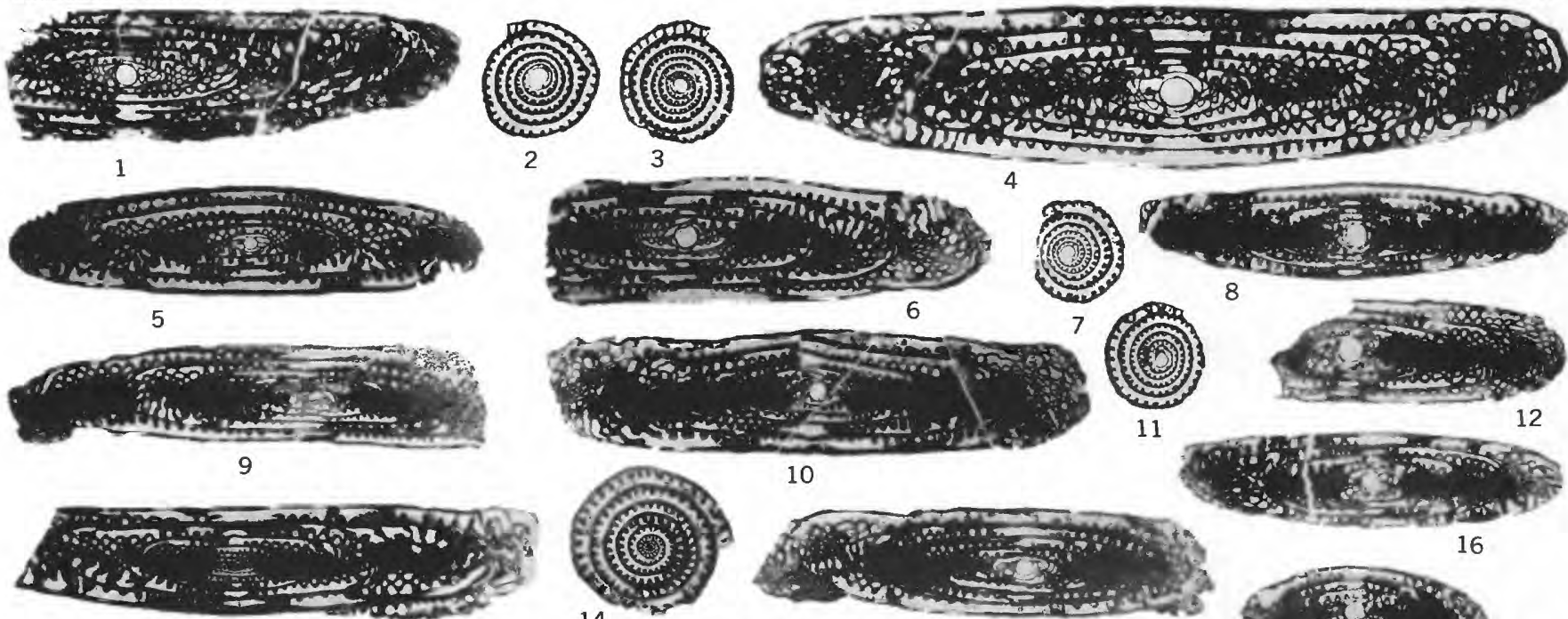

11

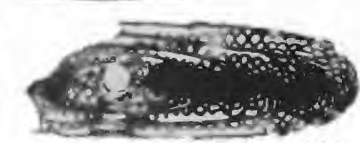

12

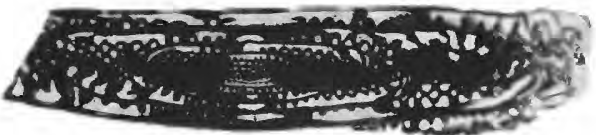

$14-7 \rightarrow-15$

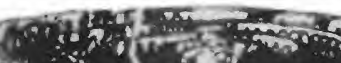

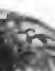

10

16

4 (u) 13

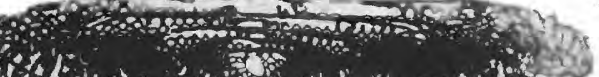

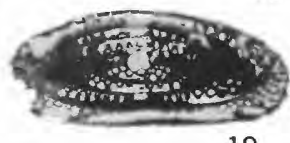

19

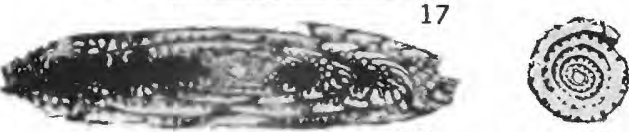

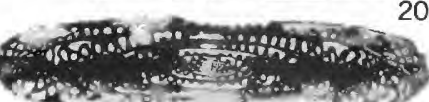

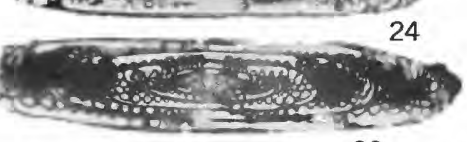

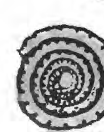

(2)
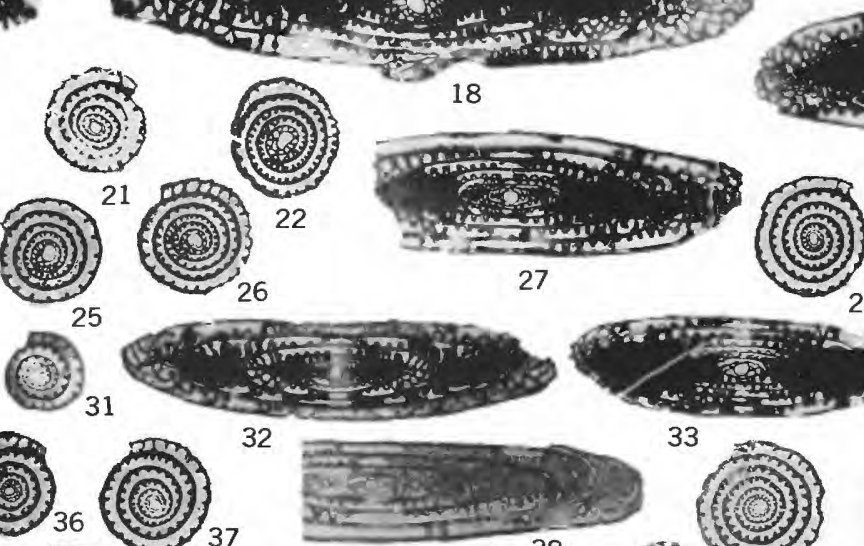

aicen

(19) $)_{42}$ कs? 38

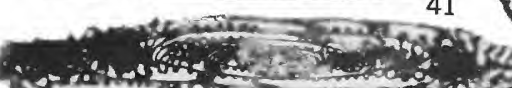

31

एका 32

42

47

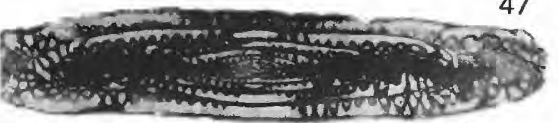

(4)

G.2.

(2)

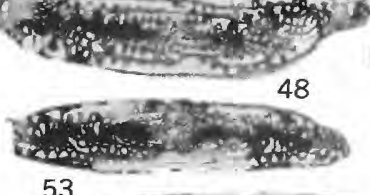

(1)

(2)

17.

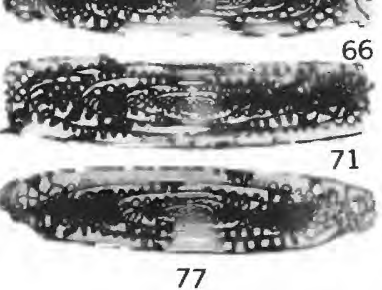

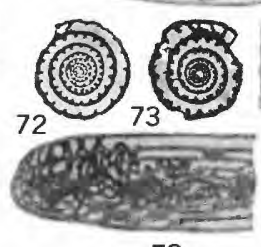

78

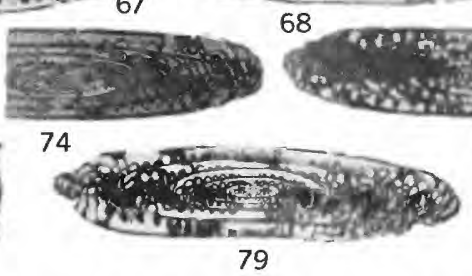

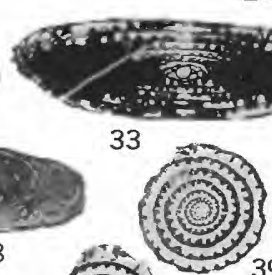

37

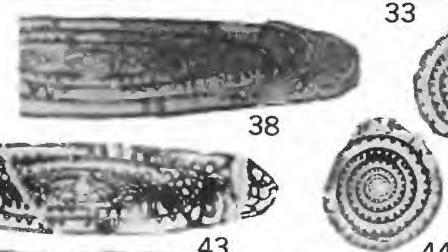

53

48 53 - 58

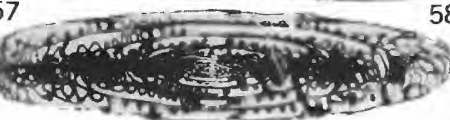

\section{1}

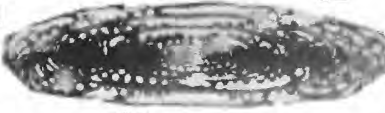

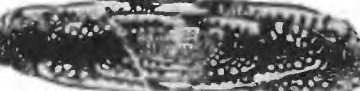

49

Gin:9:-

54

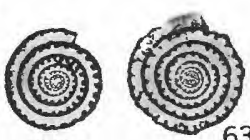

62

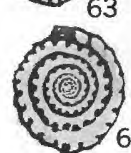

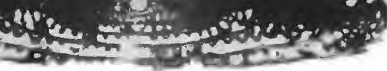
23

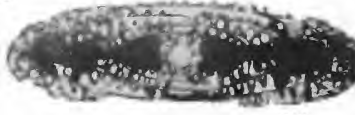

29

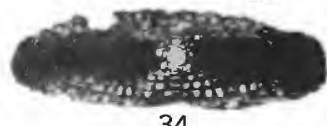

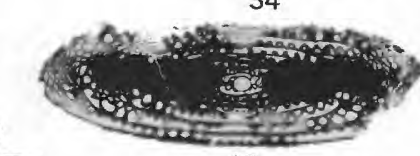

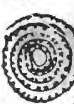

40

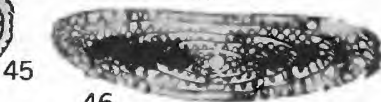
46

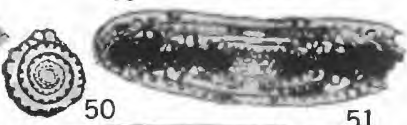
50

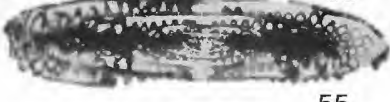

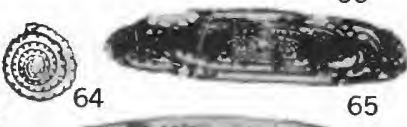

(19)

69

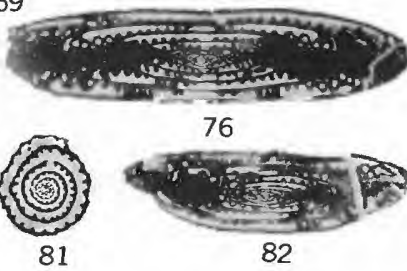

MONODIEXODINA KATTAENSIS (Schwager) from West Pakistan 


\section{PLATE 5}

\section{[All figures $\times 50]$}

Figures 1-5. Monodiexodina kattaensis (Schwager) (p. G6).

1. Views of tunnel area. Enlarged view of the proloculus and tunnel area of specimen f23793-6 illustrated on plate 3, figure 2. Solution of the wall in the tunnel area has left a thinned and irregular wall. The tectum and varying amounts of keriotheca have been removed. USNM 688204.

2. Enlarged view of the equatorial section of specimen f23790-15 illustrated on plate 4, figure 21 . Solution has left an irregularly thinned wall in the tunnel area and has removed the wall completely in some areas. USNM 688229.

3. Axial section of specimen f23790-8 showing complete solution of the wall locally in the tunnel area. USNM 688285.

4. Axial section of specimen f23802-7 showing irregular solution of the wall in the tunnel area. The wall is completely removed in the second volution toward the top. USNM 688286.

5. Axial section of specimen f23802-5 showing irregular solution of the wall in the tunnel area. USNM 688287. 

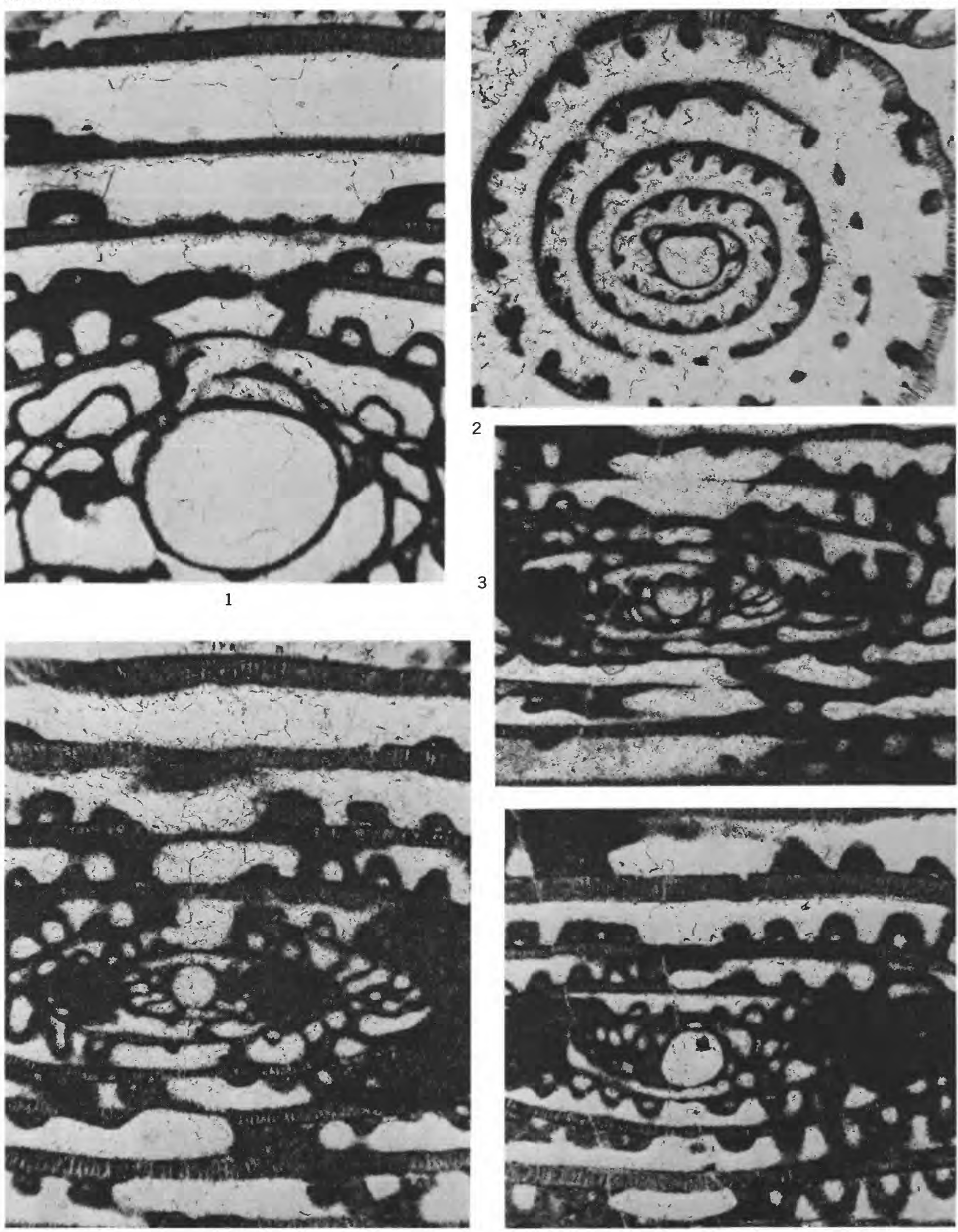


\section{PLATE 6}

[All figures $\times 50$ ]

Figures 1-6. Monodiexodina kattaensis (Schwager) (p. G6).

Variation in wall structures are shown including differences in coarseness, regularity, and thickness, and the irregular development of phrenotheca.

1. Equatorial section of specimen f23799-2 showing bulbous septa, coarse keriotheca, and only minor solution of the wall in some volutions. USNM 688288.

2. Axial section of specimen f23799-6 (same as pl. 4, fig. 65) showing thin, coarse keriotheca. Some bifurcations are visible in the walls of the upper outer volution. USNM 688270.

3. Equatorial section of specimen f23790-11 showing thin, coarse keriotheca with considerable solution of the wall in some volutions. Septal pores are conspicuous in the last few septa. Phrenotheca are visible in the next to last volution. USNM 688289.

4. Axial section of specimen f23784-1 (same as pl. 4, fig. 49) showing regular keriotheca and scattered phrenotheca. USNM 688256.

5. Axial section of specimen f23796-4 (same as pl. 4, fig. 23) showing fairly regular, closely spaced keriotheca. USNM 688231.

6. Axial section of specimen f23784-2 (same as pl. 4, fig. 27) showing irregular keriotheca and possible phrenotheca in the outermost volution shown. USNM 688235. 

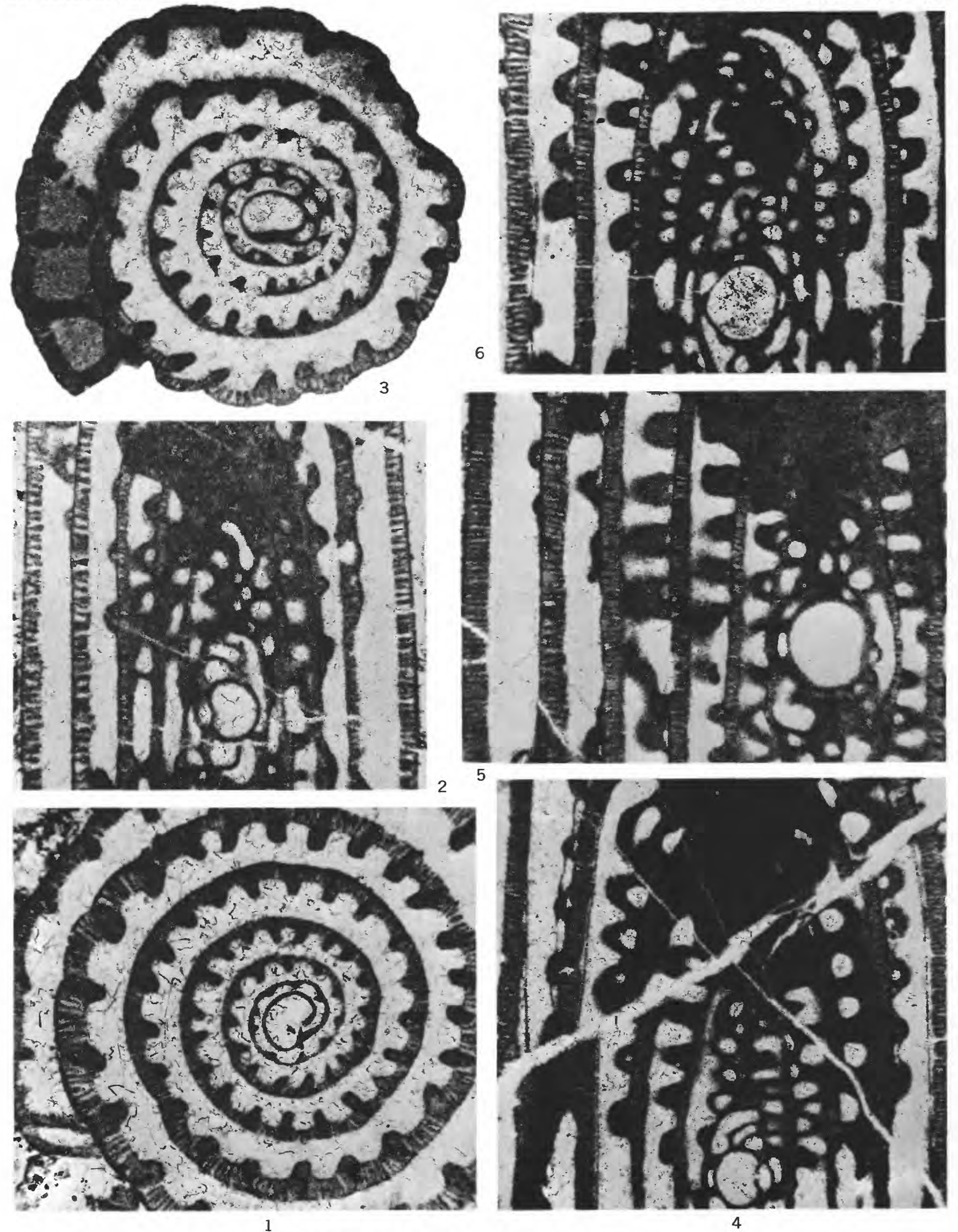

MONODIEXODINA KATTAENSIS (Schwager) showing wall structures 


\section{PLATE 7}

[Figures $1-6, \times 10,7-10, \times 50]$

Figures 1-10. Monodiexodina kattaensis (Schwager) (p. G6).

1-6. Tangential sections showing variations in septal fluting, from irregular fluting to the development of cuniculi.

1. Specimen f23783-13, USNM 688290.

2. Specimen f23794-21, USNM 688291.

3. Specimen f23790-21, USNM 688292.

4. Specimen f23799-1, USNM 688293.

5. Specimen f23792-8, USNM 688294.

6. Specimen f23795-17, USNM 688295

7. Equatorial section, specimen $\mathrm{f} 23800-5$, with one of the smallest megalospheric proloculi. USNM 688296 .

8-10. Microspheric forms.

8. Microspheric axial section (same as pl. 4, fig. 13). USNM 688221.

9. Microspheric axial section (same as pl. 4, fig. 35). USNM 688243.

10. Parallel equatorial section of a microspheric specimen (same as pl. 4, fig. 14). USNM 688222 . 

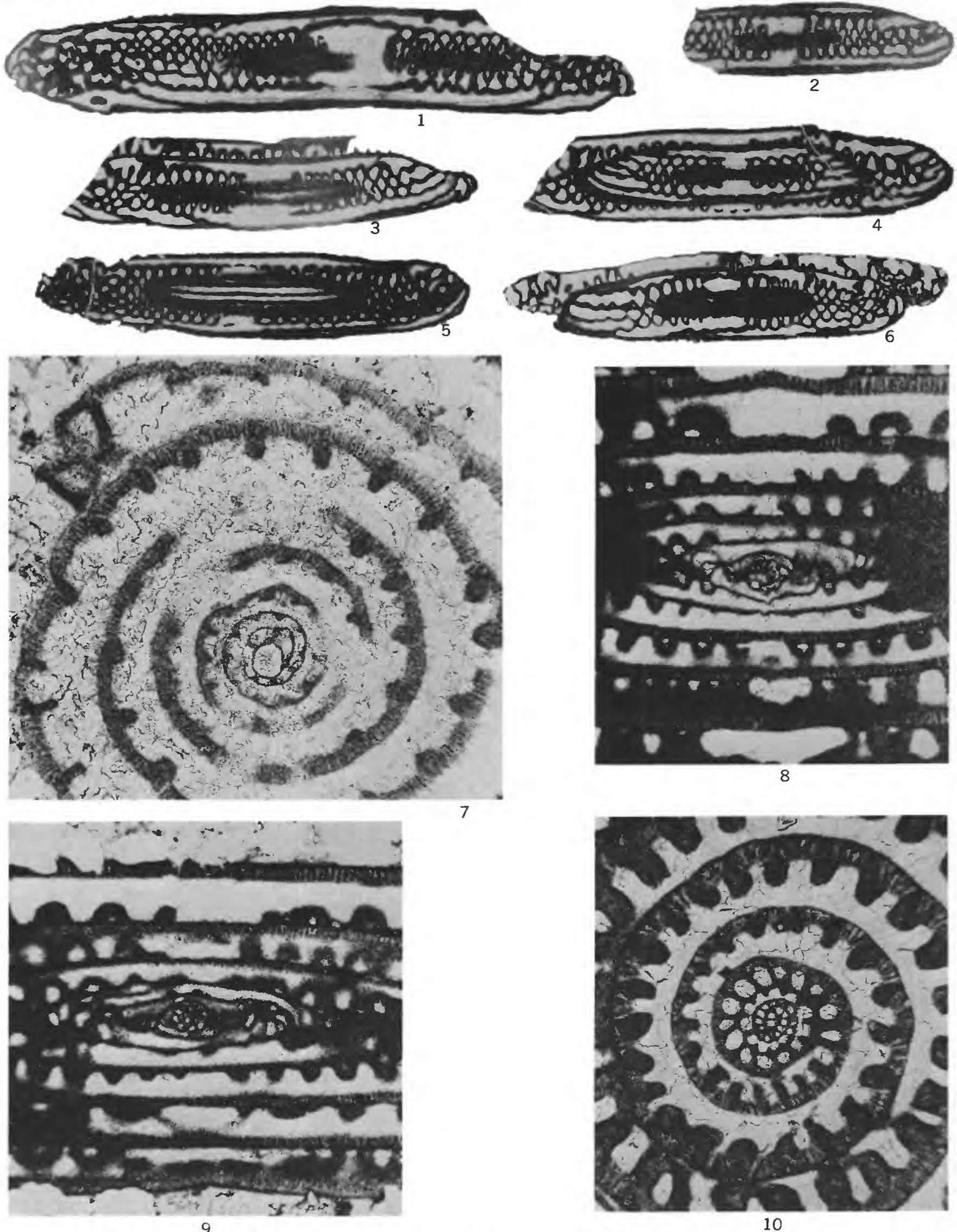

MONODIEXODINA KATTAENSIS (Schwager) showing septal fluting and microspheric forms 